3-1999

\title{
When Accountability Knocks, Will Anyone Answer?
}

Charles Abelmann

Richard Elmore

Follow this and additional works at: https://repository.upenn.edu/cpre_researchreports

Part of the Educational Administration and Supervision Commons, Educational Assessment, Evaluation, and Research Commons, Educational Methods Commons, Education Policy Commons, and the Performance Management Commons

\section{Recommended Citation}

Abelmann, Charles and Elmore, Richard. (1999). When Accountability Knocks, Will Anyone Answer?. CPRE Research Reports.

Retrieved from https://repository.upenn.edu/cpre_researchreports/7

View on the CPRE website.

This paper is posted at ScholarlyCommons. https://repository.upenn.edu/cpre_researchreports/7

For more information, please contact repository@pobox.upenn.edu. 


\title{
When Accountability Knocks, Will Anyone Answer?
}

\begin{abstract}
Pressure for increased school accountability is a distinctive hallmark of the present period of educational reform. Accountability, as presently defined in state and local educational policy, includes four major ideas: the school is the basic unit for the delivery of education and hence the primary place where teachers and administrators are held to account; schools are primarily accountable for student performance, generally defined as measured achievement on tests in basic academic subjects; schoolsite student performance is evaluated against externally-set standards that define acceptable levels of student achievement as mandated by states or localities; and evaluation of school performance is typically accompanied by a system of rewards, penalties, and intervention strategies targeted at rewarding successful schools and remediating or closing low-performing schools (Ladd, 1996).
\end{abstract}

These accountability policies are typically directed toward individual schools or teachers, and increasingly, students, as in Texas, New York, Virginia, and Florida where exit exams or proficiency requirements are central to educational reform policies. Coupled with these new accountability systems, states and localities often are pursuing policies such as charter schools and choice programs that move schools outside the existing bureaucratic structure and are intended to sharpen the focus on academic quality and student performance. Growing political and fiscal pressure on schools lies behind this conception of accountability. The political pressure stems from the increasing visibility of school performance as a policy issue at the state and local levels and the increasing capacity of states and localities to measure and monitor student achievement. The fiscal pressure derives from heightened awareness of accountability present in the literature on school reform, but to leave the definitions as open as possible.

This study is focused primarily on schools and how they construct their own conceptions of accountability. We chose this focus for conceptual and practical reasons. First, we are interested in understanding how teachers, administrators, students, and parents think about and behave toward accountability issues in schools, apart from how they respond to new external accountability systems. Schools function, in part, as accountability systems in their own right, and these systems are worth understanding in and of themselves. Second, we are interested in learning, from the variations we observe among schools, about the range of responses that schools of various types formulate to the problem of accountability. To the degree that schools vary in their responses to the accountability problem, we learn something about how conceptions of accountability are formed and how they change in the daily life of schools. Third, we are ultimately interested in joining our research on school-level accountability with research on external accountability systems to understand the sources of school-site variation in response to state and local accountability structures.

\section{Disciplines}

Educational Administration and Supervision | Educational Assessment, Evaluation, and Research | Educational Methods | Education Policy | Performance Management

\section{Comments}

View on the CPRE website. 


\title{
When Accountability Knocks, Will Anyone Answer?
}

\author{
Charles Abelmann \\ Richard Elmore \\ with \\ Johanna Even \\ Susan Kenyon \\ Joanne Marshall
}

CPRE Research Report Series

RR-42

Consortium for Policy Research in Education

University of Pennsylvania

Graduate School of Education

$\odot$ Copyright 1999 by the Consortium for Policy Research in Education 


\section{The Problem: External Accountability and School Variability}

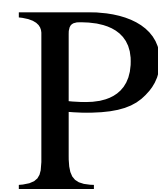
ressure for increased school accountability is a distinctive hallmark of the present period of educational reform. Accountability, as presently defined in state and local educational policy, includes four major ideas: the school is the basic unit for the delivery of education and hence the primary place where teachers and administrators are held to account; schools are primarily accountable for student performance, generally defined as measured achievement on tests in basic academic subjects; school-site student performance is evaluated against externally-set standards that define acceptable levels of student achievement as mandated by states or localities; and evaluation of school performance is typically accompanied by a system of rewards, penalties, and intervention strategies targeted at rewarding successful schools and remediating or closing low-performing schools (Ladd, 1996). ${ }^{1}$

These accountability policies are typically directed toward individual schools or teachers, and increasingly, students, as in Texas, New York, Virginia, and Florida where exit exams or proficiency requirements are central to educational reform policies. Coupled with these new accountability systems, states and localities often are pursuing policies such as charter schools and choice programs that move schools outside the existing bureaucratic structure and are intended to sharpen the focus on academic quality and student performance. Growing political and fiscal pressure on schools lies behind this conception of accountability. The political pressure stems from the increasing visibility of school performance as a policy issue at the state and local levels and the increasing capacity of states and localities to measure and monitor student achievement. The fiscal pressure derives from heightened awareness about educational expenditures as a component of state and local budgets. Further, the results of the Third International Mathematics and Science Study (TIMSS) and the National Assessment of Educational Progress have fueled public concern over what American students are taught and know, in comparison with students from other countries. ${ }^{2}$ Taken together, these pressures have created strong incentives for elected state legislators and local school board members as well as local administrators to take a continuing interest in school performance.

Nested within these developing external accountability systems are real schools: schools that have their own distinctive organizational characteristics and problems; schools that have unique student populations; schools situated in diverse and particular communities; and schools with their own institutional histories. The reality of particular schools belies the pressure for uniformity behind the emerging external accountability systems. External accountability systems assume a world in which all schools are held to the same expectations for student performance. The world that school administrators and teachers see, however, is bounded by their particular settings, by their own conceptions of who they are, who they serve, what they expect of students, and what they think of as good teaching and learning.

The long-term fate of educational reform, as it is presently conceived, lies largely in this tension between the uniform requirements of external accountability systems and the particularities of real schools. The new educational accountability systems will succeed or fail to the degree that they are designed with knowledge of how schools vary in their own conceptions of accountability.

Part of what we hoped to learn in this study, the first phase of a five-year research project, was the language of accountability as it is used and operationalized in schools. Therefore, we have chosen not to adopt the more precise definitions 
of accountability present in the literature on school reform, but to leave the definitions as open as possible.

This study is focused primarily on schools and how they construct their own conceptions of accountability. We chose this focus for conceptual and practical reasons. First, we are interested in understanding how teachers, administrators, students, and parents think about and behave toward accountability issues in schools, apart from how they respond to new external accountability systems.

Schools function, in part, as accountability systems in their own right, and these systems are worth understanding in and of themselves. Second, we are interested in learning, from the variations we observe among schools, about the range of responses that schools of various types formulate to the problem of accountability. To the degree that schools vary in their responses to the accountability problem, we learn something about how conceptions of accountability are formed and how they change in the daily life of schools. Third, we are ultimately interested in joining our research on school-level accountability with research on external accountability systems to understand the sources of school-site variation in response to state and local accountability structures.

\section{A Working Theory of School-Site Accountability: Responsibility, Expectations and Accountability}

Our research on school-site accountability was exploratory and formative in nature. ${ }^{3}$ Our objective was to learn as much as we could about how people in schools actually think about accountability in their daily work. To do this, we conducted case studies in a diverse sample of 20 schools, roughly half located in a major metropolitan area on the east coast of the United States and roughly half located in another metropolitan area on the west coast. The school sample was intentionally constructed to maximize the likelihood that schools would vary in their conceptions of accountability. For example, we chose public comprehensive elementary and secondary schools, Catholic parochial elementary and secondary schools, independent private schools, charter schools, and public schools operating under special administrative arrangements. We also chose schools on the basis of variations in communities - schools serving predominantely affluent or poor communities, as well as urban and suburban locations. And we chose schools on the basis of their size and the diversity of their student population. It is important to note that none of these schools were located in a strong external accountability environment. In this exploratory study, we looked at schools in states and districts where strong accountability was just coming on line.

We spent the equivalent of two weeks in each school. Two researchers at each site observed classes, conducted focus groups with parents and students, and interviewed teachers and faculty. The interview protocol we used in conversations with teachers and administration (included in Appendix 1) was based upon a working theory described below. The protocol includes direct, indirect, and hybrid questions, labeled according to how explicitly the accountability issue is addressed. In general, researchers relied upon the indirect and hybrid questions, and found that responses to these questions flowed more freely than with the direct line of questions. Interviews with teachers were preceded by observation of a math or English lesson. This common point of departure provided the basis upon which to ask teachers "to whom, for what, and how" are you accountable in your daily teaching practice.

To structure our field research in these case study schools, we developed a relatively simple working theory which we have continued to elaborate over the course of our research. ${ }^{4}$ It continues to be a working theory in the sense that we will rework it as we understand more about how schools grapple with accountability.

The working theory begins from a set of four key premises. The first premise is that schools actu- 
ally have conceptions of accountability embedded in the patterns of their day-to-day operations, whether they acknowledge these patterns explicitly or not. ${ }^{5}$ In order for schools to function, in other words, they have to establish channels, both formal and informal, through which individuals and the school as a whole may provide an account of behavior. How, for what, and to whom this account is given may vary from school to school. The second premise is that these school-site conceptions of accountability are organic; they are built out of the raw material of human interactions around the work of teaching and learning and running an organization. Though it may not be explicitly articulated, we assume that basic notions of what it means to be a school-assumptions about how schools, in the most general sense, operates-are influential upon teachers', administrators', parents' and students' conceptions of accountability in their particular context. ${ }^{6}$ Schein (1992) describes this group culture as "a pattern of basic, shared assumptions that the group learned as it [solves] its problems of external adaptation and internal integration ..." A school's conception of accountability, then, can be revealed in the way teachers, administrators, students, and parents talk about fundamental issues of schooling. The third premise is that participants in schools are active agents in the creation of the conceptions of accountability under which they operate, and they can be active agents in changing these conceptions. Whether consciously aware of it or not, teachers, administrators, students, and parents act out their conceptions of accountability in their daily work; these conceptions, while relatively stable, can be changed, either in response to external pressure or out of intentional action at the school level. A fourth premise is that formal, external accountability systems are only one among many that influence a school's internal conception of accountability.

Schools form their conceptions of accountability from a variety of sources, including individual teachers' and administrators' beliefs about teaching and learning, their shared conceptions of who their students are, the routines they develop for getting their work done, and external expectations from parents, communities and the administrative agencies under which they work.
Our working theory posits a set of relationships among three factors: individual conceptions of responsibility; shared expectations among school participants and stakeholders; and internal and external accountability mechanisms. An individual school's conception of accountability, in our view, grows from the relationship among these three factors (Wagner, 1989).

\section{Responsibility}

Individuals who are parties to schooling - teachers, administrators, students, and parents-have their own personal values that define their responsibilities toward others. Teachers, for example, may have strong views about their personal responsibility for student learning, or the degree to which students and their families share this responsibility. Administrators may feel personally responsible for influencing teachers' instructional practice in particular ways, or they may locate responsibility for instructional practice primarily with teachers. The distinguishing characteristic of responsibility, in other words, is that it is personal and individual in nature and it stems from the values and beliefs of individuals. Individual conceptions of responsibility may come from a number of sources-from the life experience and moral background of the individuals, from their education and training, from their beliefs about the social determinants of student learning, and from their interaction with others. From the perspective of our working theory, we do not assume that individuals' conceptions of responsibility come mainly from their work environment or from formal accountability systems. Instead, subscribing to Lortie's (1975) assertion that teaching occurs primarily in isolation, we assume that organizational and external influences may play a part in teachers' perceptions of their role, but that individual values are certainly influential.

For example, individual English teachers may have strong beliefs about what constitutes a good essay, 
what constitutes a good book for students to read, what might be an acceptable number of books for a student to read in a year, or what might be an acceptable amount of homework to assign in a given week. They may also have strong beliefs about the capacities of their students to learn certain things. Further, teachers may include among their responsibilities, students' emotional and physical well-being, and in some cases individuals may even perceive this responsibility as taking priority over curriculum requirements. Beliefs may be shared among English teachers, or they might lie in the domain of individual teacher discretion and vary widely among English teachers. To the degree that beliefs lie in the domain of individual discretion, and relate to one's individual beliefs about his or her own behavior, we call them responsibility.

\section{Expectations}

Expectations, by contrast, are collective in nature and they characterize the shared norms and values of school participants developed to get the work of the school done. They are formed out of relationships among individuals, and they operate in often powerful ways to shape individuals' behavior and values. For example, first grade teachers may have shared conceptions in a given school about how fluently first graders should be reading by the end of the school year. Or, they might have expectations of how much noise is tolerable from their colleagues' adjoining classrooms, or of what constitutes good student decorum in the hallways. Parents may expect teachers to treat their children in certain ways in the classroom or to prepare their children for certain postschool futures. And, teachers may have expectations regarding the amount of time parents should spend supervising homework. Teachers and administrators together may form certain expectations about what academic work students from "their" community are capable of doing; these expectations may or may not be shared by students and their families.
The distinctive feature of expectations is that they are collective in nature - shared among individualsalthough not necessarily with complete consensus among all the individuals in a given school. Further, expectations are beliefs about others' behavior, though individuals may include themselves within the collective for whom they hold these expectations. Certain expectations might be widely shared among all parties - teachers, administrators, students, and parents - or expectations might vary among groups or factions within a school. Different groups of teachers, for example, might have different expectations of what constitutes adequate student performance or decorum in the classroom. Teachers might have one set of expectations for students, and parents might have another. So the fact that expectations are shared doesn't necessarily mean that they reflect a consensus among all parties in a given school.

\section{Accountability}

Accountability mechanisms are, literally, the variety of formal and informal ways by which people in schools give an account of their actions to someone in a position of formal authority, inside or outside the school. Some accountability mechanisms are internal to schools. Principals, for example, may require teachers to provide copies of their lessons, to write a daily schedule on the blackboard in their rooms, or to be available for supervisory duty in hallways, playgrounds, or lunchrooms. Some accountability mechanisms are external to schools. School districts may administer periodic student assessments, for example, and use the resulting data to influence what teachers teach. Accountability mechanisms, whether internal or external, take a wide variety of forms. They might be explicitly formal in character, as when written in a school handbook or district or state policy. They might also be relatively informal, as when a principal communicates to teachers that they should keep the noise level down in their classrooms, then engages in explicit monitoring of classrooms. Likewise, accountability mechanisms vary consider- 
ably in their consequences for success or failure. The consequences might be communicated, with relatively low stakes, such as a principal's approval or disapproval communicated to a teacher for something that happens in that teacher's classroom. Or accountability mechanisms might carry relatively high stakes, as when a principal publicly praises or criticizes a teacher for disciplinary practices or when a district publishes in the local newspaper student academic performance data by schools.

In the context of our working theory, accountability carries a specific meaning. When we asked people in schools about accountability, we were interested in: accountability for what; how they were required to give an account of their actions; and the consequences or stakes for failing to do so.

In our working theory, responsibility, expectations, and accountability operate in a close mutual and reciprocal relationship with each other, and this relationship takes a variety of forms in different schools. This relationship is captured in Figure 1. Individual conceptions of responsibility may influence collective expectations, or alternatively, collective expectations may influence individual conceptions of responsibility. Similarly, individual conceptions of

Figure 1. Interactions and Alignment

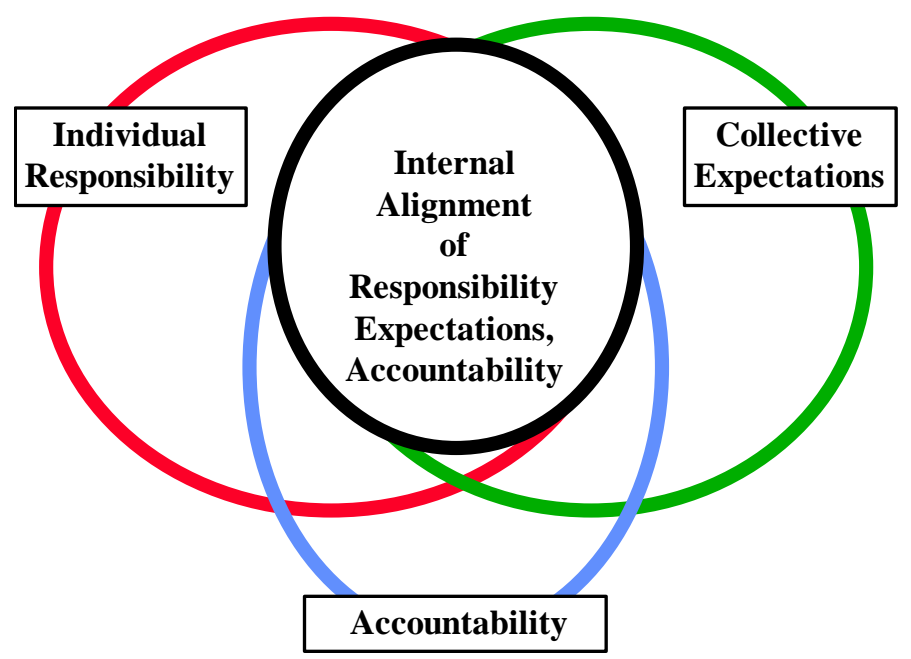

responsibility or collective expectations may influence formal or informal accountability systems, or vice versa. In Figure 1, we mean to convey that a given school's response to the problem of accountability is the result of how it resolves the tensions, inconsistencies, and complementarities between individuals' personal values, their shared expectations, and the mechanisms by which they account for what they do.

Implicit in the model presented in Figure 1 is the normative view that schools are likely to have more powerful internal accountability systemsformal or informal-if the values and norms embodied in these systems are aligned with individual conceptions of responsibility and collective expectations in the school. That is, internal accountability systems are likely to be powerful in their influence over individual actions to the degree that they are consistent with the values represented in individual responsibility and collective expectations.

Alignment can be produced in a variety of waysfor example, by deliberately choosing people who share a common set of values to participate in the school or by deliberately using the structures and processes of the organization to socialize people to a set of common views. To the degree that individual responsibility, expectations, and internal accountability systems are not aligned, one can expect various degrees of incoherence among individual beliefs and collective norms, and relatively weak internal accountability systems.

We have said nothing yet in this analysis about what individuals or schools consider themselves to be responsible or accountable for. To say that there is a high degree of alignment between responsibility, expectations, and accountability is to say nothing specific about the purposes for which the school is aligned. Schools could, for example, have a high degree of alignment about values that stress student academic performance, or they could 
have alignment about values that stress order and discipline in the classroom and hallways, but little or no agreement on academic goals. Alignment, then, refers to the consistency and strength of agreement inside the school, not the subject of that agreement.

Also implicit in the Figure 1 model is a normative view about the relationship between external accountability systems and the internal life of schools. If the power of internal accountability systems is a function of the alignment of responsibility, expectations, and internal accountability mechanisms, then the power of external accountability systems is a function of the alignment between the norms and values represented in these systems and the internal accountability mechanisms of schools. The effect of external accountability systems is mediated by internal accountability mechanisms. Schools might, for example, have a high degree of internal alignment around values and expectations that are quite inconsistent with the requirements of local or state accountability systems. Or alternatively, schools may not be aligned around individual responsibility, collective expectations, and internal accountability, and, therefore, respond incoherently to relatively clear guidance from local or state accountability systems. In other words, how a school responds to external accountability systems is largely determined, not by the details of those external systems, but by the degree of alignment between the schools' internal accountability mechanisms and the requirements of the external accountability system.

For example, a school might have relatively weak common expectations for teachers and students and relatively weak internal accountability structures. In such a school, teachers' conceptions of their work would be largely driven by their individual sense of responsibility. As represented in Figure 2 on page 8, the responsibility area would dominate our Venn diagram, and there would be very little overlap between the circles. Similarly, internal accountability measures, if they exist at all, would have relatively little influence. This school would be atomized, that is, fragmented into individual or very small units. Teachers would form their expectations for students and their ideas about what and how to teach, largely out of their individual conceptions of responsibility. This school's response to any external accountability system, we predict, would reflect its internal incoherence. The requirements of the external system would be translated into idiosyncratic values and practices by individual teachers.

Another type of school might have relatively strong common expectations about certain shared norms, and these expectations might be aligned closely with teachers' conceptions of personal responsibility. The graphic representation of this scenario is seen in Figure 3 on page 17. Expectations dominate the diagram, but to a lesser degree than does responsibility in Figure 2, and with a more balanced relationship between the responsibility and expectations areas. A school might arrive at this state by recruiting teachers who already share a common view of teaching and learning and by creating internal structures and processes through which teachers share their personal beliefs and develop common expectations of each other. These shared expectations might be similarly extended to parents and students, by recruitment of like-minded clients or by active socialization. In some instances, coherence might be achieved by a community actively imposing its values on the school, through sustained parent involvement or political influence in the recruitment of teachers and administrators. Such a school might have either weak or strong internal formal accountability mechanisms. The school might simply operate on a daily basis, and teachers might define their work, based on shared expectations that are aligned with their sense of personal responsibility, with relatively few explicit rules or procedures designed to hold individuals accountable for their work. Or a school might extend its agreement at the level of responsibility and expectations into a relatively explicit internal accountability system of rules and proce- 
dures that provide a basis for teachers and students to account for their actions. This scenario is represented by Figure 4, on page 27, where the strength of alignment between the three areas, and particularly between responsibility and expectations, functions as an informal accountability system.

This type of relatively cohesive school is characterized by a high degree of alignment between individual responsibility and collective expectations, and can possibly be complemented by a relatively explicit internal accountability system. Such a school might, in our working theory, respond to an external accountability system in a number of ways, including: accepting and internalizing it; rejecting it and developing defenses against it; or incorporating just those elements of the system that the school or individuals deem relevant. Response to the introduction of an external accountability system would, we assume, depend upon the degree of alignment between the purposes of the external accountability system and the internal norms of a school.

\section{Accountability for What, to Whom and How?}

A final part of our working theory addresses the issue of the purposes behind accountability systems. Most formal external accountability systems are predicated on the assumption that schools should be held accountable mainly for student academic performance. Viewed from the school level, however, the picture is far more complex. We addressed the issue of purpose by posing, in each of our schools, the question: For what are you accountable, to whom, and how? Schools are characterized, not surprisingly, by a wide variety of answers to the for what question, and the various answers they give to the for what question, not surprisingly, have very different implications for how they answer the to whom and how questions.
In some schools, for example, teachers have explicit theories about the relationship between the characteristics of the children and the communities they serve and for what they as teachers are personally responsible or for what they are collectively accountable. Some teachers, for example, believe that their responsibility and their formal accountability is, and should be, heavily shaped by the socio-economic background of the children they teach. Children living in poverty, they argue, require social supports in the classroom and in the school that children not living in poverty do not require. When asked for what they are formally accountable, these teachers were apt to rephrase the question using the language of responsibility in place of accountability. Some teachers answered the for what question by stating their belief that they are responsible for providing a safe, nurturing environment for children. Other teachers believed that the socio-economic background of the children they teach should have less importance in determining for what they are responsible or accountable. They answered the for what question by stating their belief that they are responsible for students' academic performance or their future success in school. These answers to the for what question have very different implications for how teachers answer the to whom and how questions. Teachers who see themselves as primarily responsible for providing a nurturing environment, for example, are more likely to say they are accountable to the children and their families.

In the following sections, we have organized observations from our first year of exploratory fieldwork into three categories, based upon the schools' responses to the problem of accountability. We reiterate that our findings are limited by the fact that the schools in the exploratory study were not located in strong external accountability environments. Within each section, we feature a lead case, followed by several supporting cases that represent variations on the theme of the lead case. The categories are by no means exhaustive of the characteristics we observed in these schools, nor are the distinctions between categories quite so pronounced as they may 
appear in this format. No school is an absolute case of just one theme, but some are more typical than others in reflecting that theme. ${ }^{7}$

\section{Atomized Accountability: Individual Responsibility Dominates}

For many teachers, the idea of accountability has little or no tangible reality in their daily work. They operate essentially as solo practitioners in isolated classrooms, relatively detached from the influence of outside forces. In this section, we examine four cases where this daily reality of isolation dominates conceptions of accountability. The lead case, Phoenix Charter School, which we believe typifies the theme of this section, is a relatively new inner city elementary school, operating under a charter from the state. Phoenix students are disproportionately poor and minority. Phoenix may be unique because of its charter status and its corporate sponsorship, but in many ways it is similar to the other schools in our study that serve urban populations. Figure 2 indicates, by the relative size and independence of individual responsibility, that there is little internal alignment in this category of schools, and individual discretion is the primary mode of accountability. Gateway, a small urban Catholic K-8 school situated across the street from a housing project, serves, like Phoenix, a heavily minority and disadvantaged student population. Stevens is a large urban middle school, with a reputation for being relatively successful with its working class and disadvantaged student population. Hutch-inson is a large nineteenth-century public high school with a once-proud academic legacy and a recent history of student behavior problems. In all of these schools, accountability begins - and usually ends — at the level of individuals, particularly individual teachers.

\section{Phoenix Charter School}

Figure 2.

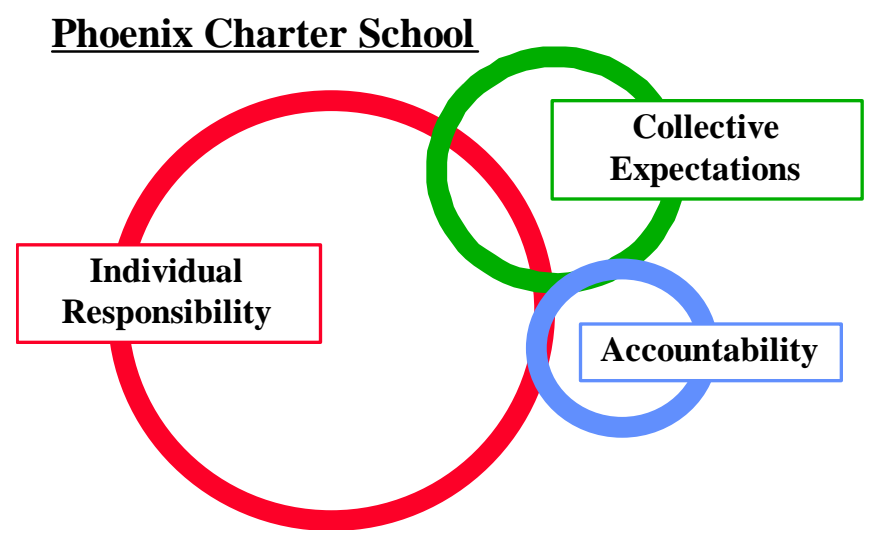

To Whom Are You Accountable? The Teacher-Student Relationship at Phoenix

Proponents of charter schools often claim that they are "the most accountable" kinds of schools. Schools that apply for and are granted charters must persuade their governing agency (the city or state) that they are able to teach children; in return for which they receive funding and autonomy from many state and local regulations. Most charter schools are reviewed annually through site visits and reports, and those who fail to meet the terms of their charter are subject to its revocation. In this sense, some say they exemplify a relatively clear and explicit kind of external accountability — one focused on parent choice and state oversight.

We might therefore expect that teachers at Phoenix would be concerned with this formal accountability; that they would be concerned with making sure their students' test scores increase, or with teaching the curriculum mandated by their sponsoring Corporation, or with their ongoing evaluation by their administrators. But, in the case of Phoenix, they are not. Teachers barely mentioned these kinds of formal accountability mechanisms in the course of our interviews. Instead, they spoke with 
passion and enthusiasm about being most "accountable" to the one group that has no formal power in schools at all - their students. In speaking about their relationships with students, they tended to use the term "accountability" to refer to what we have called personal responsibility. For Phoenix teachers, "accountability" is largely defined in terms of their individual responsibility toward students, rather than any formal or informal set of rules or procedures by which they account for what they do.

For example, one teacher, when asked to whom he is accountable, responded: "Kids. Twenty-eight kids ... that's why I'm here. That's why we're all here. So they can get educated. Get them ready for what they can expect when they get older." Such a response defies the traditional notion of accountability as a reciprocal relationship with consequences, because although teachers claim accountability to their students, students in this and other schools have very little, if any, formal influence. The teacher-student relationship is inherently one where teachers are given authority over their students, a position made fast by the schools' in loco parentis function. In return for the authority granted to teachers, teachers accept responsibility for their students. While students may certainly complain about their teacher, or act in a way that makes her job easy or difficult, they do not themselves exercise any authority over the teacher or hold her accountable in any meaningful sense of that term, or claim responsibility for the teacher's actions. This most essential of school relationships is thus one-sided: teachers accept personal responsibility for the students entrusted to them, but that responsibility is unreciprocated.

Students are minors, so society grants authority and responsibility to their parents or guardians. One would therefore expect that parents would represent their children in the teacher-student relationship: teachers might not be accountable to their students, but they could be accountable to their students' parents. Some Phoenix teachers, when asked, did mention students' parents as the people to whom they were accountable, but did not feel that parents were accountable to them in return. While there was a core of very involved parents, most Phoenix teachers expressed frustration with the level of parent involvement. One teacher cited her nonattended parent conferences: "Last year I called them ... I would come in on a Sunday and nobody would show up. So that was kind of ... sad. I just expected parents to care a little bit about their child's education. It's not like I ask them for too much either." Other teachers who said they were accountable to parents said they assumed that parental noninvolvement implied satisfaction. One teacher summarized his relationship with parents:

The fact that I don't really hear from them probably indicates that they're satisfied with what is happening. I make [laughs] that assumption ... I don't have the time to call parents when kids are acting up and suspended five days in a row from class. And I wish that they would call me. I mean, it's their kid; they should be calling me and letting me know if they want to know about their kid. They need to call me. So I wish they would call more. But any time I do call them, they're usually pretty supportive.

A Phoenix administrator pointed out that she has learned over the years that public schools cannot hold parents accountable for anything. There are always going to be parents who will be uninvolved, she said. This lack of parental involvement again presents teachers with a onesided, unreciprocated relationship, which keeps them from being fully accountable to parents and from accepting parental accountability in return: the majority of parents simply aren't there. Because teachers are alone in the teacher-student-parent relationship, they assume more responsibility in it and for it. 
Given the primacy of the teacher-student relationship and its one-sidedness, it is not surprising that when we asked Phoenix teachers, "To whom are you accountable?" many answered, "Myself." When we asked one teacher "who checks" to see if she is doing her job, she said, "No one, but I know. I don't want them [her students] to be lost." This attitude extends not only to teaching, but also to its auxiliary functions, such as record keeping, about which one teacher said: "No one has ever checked it, and, to tell you the truth, I'm not very organized about it. I mainly am most accountable to myself. If I am not doing what I am supposed to be doing, then I am failing, and I have a problem with that." Other teachers spoke of self-checks such as their ability to "sleep at night," or to "look in the mirror." Again, what these teachers were calling "accountability" is what we have defined as their own responsibility.

Based upon the organizational structure of schools, administrators are the obvious people to whom teachers are accountable. Administrators hire, evaluate, and fire teachers; in return administrators are expected to provide supplies, curricula, and support. However, administrators are excluded from the basic teacher-student relationship upon which the work of schools is founded. Perhaps this outsider status explains why many teachers mentioned being accountable to their administrators only occasionally, and then only after mentioning students, parents, or themselves. This ambivalence is reflected even in attitudes toward evaluation, which one would expect to be the consequence that gives accountability its bite. One teacher said of his administrators' evaluation: 'I don't see them [administrators] coming up and saying, 'This is what you need to work on.' I feel I'm doing a good job. The honest truth is that I really don't care [laughs] if they approve or not. I feel what I'm doing is correct."

Other teachers told us of quietly disregarding administrative mandates such as curriculum. For example, although the Corporation curriculum does not include spelling, one group of four regular classroom teachers and a special education teacher told us that they teach spelling anyway, using materials they purchased themselves. One teacher said:
I'm traditional. . . They need to learn how to spell. So I start off with things around the room, and science words, and now I've bought a spelling book... boring. But they need that. They need that background. They... need a stronger way to decipher words.

Another teacher agreed: "Spelling isn't a curriculum in our school. I believe children need to memorize ten spelling words a week. So that's something that I do extra, and I give them packets to do it." These teachers also said that there is "no time" to teach spelling, so they send it home with their students even though, one reported, they are "not supposed to."

Because teachers have little interaction with administrators other than the evaluations that most of them disregard, and because they do have a lot of interaction with their students, it is logical that their accountability to administrators is weaker than is their sense of responsibility to their students. As noted earlier, when there is weak internal accountability and weak expectations of teachers, teachers' sense of responsibility rules.

\section{Teacher Responsibility for What?}

When we asked Phoenix teachers for what they are accountable, their replies fell into three main categories: students' learning, order, and students' well-being. In answering questions about their accountability, however, teachers frequently referred to their own sense of responsibility for learning, order, and well-being. The extent to which all teachers described feeling responsible for these areas places them in both the individual responsibility and collective expectations categories as defined in our study. 


\section{Student Learning}

Student learning is the most obvious function of schools, and the school people mentioned it as a matter of course. Teachers spoke sincerely and eloquently about their work with students as this Phoenix teacher did:

Mostly I feel like I'm accountable to my students; I'm here to teach them, to make sure that they're learning what they're supposed to learn, and to present it to them in the best way that it's going to get to them.

Another teacher said:

I'm supposed to teach them, and I plan to teach them. Like now I'm doing report cards, and when I write something down, I expect to be able to stand behind it and say, 'I did my best to teach this child' and 'I did my best assessing this child' through tests or observation or cooperative learning and everything like that.

And another teacher said:

My job is to teach the curriculum, to suit all the children in my classroom, regardless of their learning ability. So that's my responsibility. I need to find a way to teach everybody so that they... [are] basically on grade level.

These three teachers use the language of responsibility. Their comments were very I-centered: "I feel" and "I'm here" and "I plan." There is an implied assumption that they are "supposed" to do this, that the "job" requires it, and that someone might ask them to stand behind their assessment, but when we asked teachers where they got their ideas of what it means to be a teacher, they spoke not of their administrators, or their teacher education programs, or their colleagues, but of their own families, their own teachers, and their core values. One teacher said:
I grew up in a family that was very-I started working when I was 14. They believed in work, they believed . . every summer, every holiday, you went to work with the rest of the family. You did your part... I've always been raised, myself to . . you do the best at what you do, or don't do it. Find something else to do ... So as far as teaching, this is huge. I'm teaching 28 children . . You think of it kind of like a privilege. My God, I've got these little minds, little brains, and I can fill them with all this good stuff and hope that they take something with them to the next grade.

Teachers' language revealed their intense desire to find "the best" way to teach "all the children." These teachers' responses were common among Phoenix teachers; so common that they confirmed the observation of another teacher that Phoenix has its own culture, one of: "The kids are going to progress. And you're going to make sure that happens."

\section{Order in the Hallways and Classrooms}

For student learning and progress to take place, everyone at Phoenix believes that order is absolutely necessary, and this is the second area for which teachers claimed responsibility. Their results are immediately noticeable: Phoenix is bright and clean and free of graffiti. Students sit a certain way on rugs (cross-legged), line up a particular way when leaving (each student standing in a square floor tile), and stand a certain way in the halls (arms behind backs). The school has a citizenship program of rewards and punishments which formalizes the emphasis on student behavior, and most teachers have their own point systems as well. When asked what to look for in a prospective job candidate, most teachers immediately mentioned the candidate's ability to discipline. One teacher elaborated: 
I would say it has to start with discipline. I would either just tell [prospective candidates] point blank what we do here about discipline and what our expectations are as far as dress policy; and no talking in the halls; and when someone's talking, pencils are in the pencil holders; and people are not leaving their seats without permission; and using the bathroom all as a class at the same time. I would either just tell them straight up that's what we do, or I would ask them first what their approach to schooling is. And if they start talking about theory and great curriculum and stuff like that, and do not talk about the nuts and bolts of what you have to deal with during the school day... then I would probably think twice. . . I would say. . . "This is how we do it. And if you don't like it, then, if you're more ... touchy feely, and let the kids have this say and that say, then this isn't really going to be the place for you ..." Eventually you can get the kids to where they can do that. But initially it's got to be discipline, discipline, discipline.

At times, it appears order becomes an end in itself, rather than a means toward the end of learning. For example, we observed a lesson at Phoenix where directions were given after each math problem, "Chalk down! Chalk up!" and for each step in clean up, "Collect paper towels. Put your slate in the middle, on top of the box. Bring me the box ... Table 2, go wash your hands." At the end of class, the line for lunch had to be redone-lights off, students sent back to their seats, free time at the end of the day taken away, and the line re-formed. Each of these directions takes class time-in giving them and in following them. One could argue that time spent giving and following such directions saves time later as students learn procedures and can move from task to task efficiently. But the lesson we observed was mid-year, and the directions did not seem necessary to that lesson. There seems to be no reason a lunch line would have to be re-formed except to maintain order as an end in itself.

The expectation that teachers will maintain order is one of the few expectations with which staff associate and anticipate profession consequences. They cited unsuccessful teachers who were not asked to return because their classrooms were "crazy" or administrators had to intervene frequently. By implication, teachers know they are doing a good job if their classrooms are quiet and administrators do not intervene. We asked one of the Phoenix administrators about this emphasis on order, and she offered two explanations: first, such order is necessary in order to maintain safety within the building, especially in case of fire; second, such order teaches children how to behave in society, which is necessary for them to be successful.

\section{Students' Well-Being}

Students' well-being is a broad concept that encompasses and depends on academic learning and discipline. That is, student well-being is necessary in order for students to learn, and their learning will improve their well-being. The urban teachers in our study shared what can be called almost a sense of mission to improve their students' lives - a mission that crosses teachers' race, gender, and class lines.

Some of the Phoenix teachers worried about their students' survival. One teacher said of his students: "I . . . hope for them to live to see their adulthood . . . by not making a bad decision that will cost them their life. That's what I fear the most because they are inner city kids." We heard this teacher and others in his cluster repeatedly talk to and about their students in terms of making "good decisions," a phrase usually referring to student behavior. One teacher called this kind of awareness "preparing students for life." We asked him how he would "teach life" in the lesson we observed and he said: 
[Today] I didn't go off on a tangent, saying, "If you don't follow directions, then you'll get fired from a job," or whatever. Today it didn't really come up. But if there was a conflict there in the class today, then I might have gone off on, "Well, you handle this situation out on the street, then you might end up dead or you're going to be locked up. If you handle that situation that way on the job, with a coworker or your boss, you might get fired from your job. Or if you're at school, you might get kicked out of school. If you're not turning your work in on time, you're going to get failed; you're going to get F's in college, and you're going to get kicked out of college." That sort of thing.

Other teachers talked of teaching children "different values from home," such as not resolving a conflict through hitting. Some teachers talked of being role models (especially teachers of color), or of meeting students' emotional needs. At times these responsibilities lead to ambiguity about the teacher's role. One teacher spoke of being both an emotional support and a disciplinarian. When asked what her students expect of her, she said:

Too much, actually. They think I'm their friend. They think I'm their mother. [She imitates:] "Ms. Dawson, can you unbutton my ... ", "Ms. Dawson, can you do that?" And they would feel sick until I would say, "It's okay, sweetie," and give them a hug, and then they're fine for the rest of the day. But then it gets in the way of discipline, because when I say, "Okay, now study for your science test," they're around me, they're giving me a massage ... and then I'll go crazy and then I'll start yelling and [she demonstrates:] "Get in line. I'm not your friend. You need to get in line right now." [Imitates student:] "Geesh! I was just doing this!" And then, I have a kid, Nikia . . . who writes me letters . . I should love her more, and why do I love this other kid? ... And I say, "Look, Nikia, I'm your teacher, not your friend." [Imitates Nikia:]

"You can be my friend and my teacher at the same time." And I said, "No, I can't." . . I have two kids who lost their mothers ... and they both ... desperately need a female somebody.

Another teacher, wishing for more school social workers, talked about the tension between teaching students reading and acknowledging their difficult home lives:

Schools are becoming more than a place to learn ... Some of these kids come here at six in the morning, early morning, and they are here until seven-thirty when their parents pick them up and ... the only time they are going to get counseling or anything is [in] school and I think the role of school needs to be looked at and how it should be changed. I definitely think more counselors. Half these kids have a parent in jail or a sibling. They come from neighborhoods where they can't go outside and then they expect them to read these silly books?... And I do think it is important for us, as teachers, not to excuse their behavior from where they came from, but to understand it . . . Why is it important to read this book? What do we want out of it? And to really focus on: What we have gained by doing this? This is really hard for a kid to see.

These teachers claimed responsibility for modifying their teaching practice in keeping with their students' needs, whether those needs are academic, social, or psychological.

\section{Other Schools}

\section{Gateway Elementary School}

One might expect teachers at Gateway, an inner-city Catholic school, to talk about accountability in 
religious terms: of being accountable ultimately to God or, on a more earthly plane, to the archdiocese. But they do not. Neither is religion an emphasis for learning: the principal reported that teaching students religion is not as important as "educating them so that they'll be able to better themselves in life ... and sharing values with them." Perhaps this lack of emphasis on religion is due to the fact that, although the new principal and one teacher are nuns and most of the staff is Catholic, most of the students are not Catholic.

In this school where teachers were concerned with their students' very survival-for example, "I pray that they can make it through the summer without getting killed"- - the teachers seemed to feel so responsible for their students that they were defensive about anything that referred to their students' poor academic performance, be it low test scores or letter grades. On report card day, several teachers told their students, "Not everyone is an A student," and "Being average is OK as long as [you] are trying." While these remarks were probably reassuring to students, they did not reflect the priority on learning that the principal desired.

At Gateway, when asked about responsibility, every teacher spoke about caring for the children. One teacher said: "I think most of us are here for the welfare of kids." She continued to talk about their welfare as follows:

We are aware of the fact they're here for education. On the other hand, many kids are coming from homes with alcoholism and the last thing they care about is an adjective. So if I get hysterical about an adjective, I'm really doing them harm. So their welfare comes first before their educational process, whatever. I think we want them to be happy, believe that in an atmosphere of happiness, friendliness, making friends, safety here, that there's not going to be violence in the school yard, that there's not going to be drugs in the building, that they are safe and that they know that there are people here who really care about them, because I would say that we do. We really do. And then secondly we want them to succeed in high school and in college.

In the past, reported the principal, Gateway stressed the importance of safety and support rather than teaching and learning. This tension between support and learning was revealed in a story she related about sharing Gateway's low test scores with her staff, and what she perceived to be their response: "Ho-hum ... Well, it's an innercity child who has no family, no motivation, is constantly underfed, tends to sleep in the classroom, and it's very difficult to reach them." Not only were the teachers more concerned with their students' affective needs, but they also did not believe that the tests were a worthy measure of their students' learning. One teacher commented about the tests: "We don't do anything with them [the tests]. They do not relate to a lot of what these youngsters know. And they [the students] are not readers, so it is very difficult, I think, to have them do as well as they should."

The principal's concern about academic learning was supported by the archdiocese, which provides a formal curriculum and teaching guidelines. But the teachers were unevenly concerned with what the guidelines were or what they were to cover by the end of the year.

Gateway is a school with little formal accountability to anyone outside the classroom, very low teacher expectations for academic potential, and very real teacher concerns about students' survival. Teachers seemed to define their roles as that of parent instead of teacher, responsible for students' well-being and accountable primarily to themselves, with no theory about how to combine attention to affective needs with academic learning. 


\section{Stevens Middle School}

Stevens is another school with little cohesion among the staff. When asked about accountability, one teacher responded, "[It's] individual all the way." Another teacher, when asked who is accountable to him, said, "I think the students are accountable to me, but who cares? Really, who cares? Except me." Here, too, there was a historical lack of formal accountability. The school has scored well on tests in the past, but the tests have variable impact on classrooms. Instead, teachers reported autonomy over their practice and content. Like other teachers in our study, they said they were accountable to themselves, to their students, or both. There was an emerging sense of formal accountability to the principal, because the district's new educational reform plan influences his retention, but this formal accountability was based on the staff's "trust and loyalty for the past twenty years."

Administrators and teachers at Stevens agreed that their responsibilities reach beyond the schoolroom door, but there was little commonality in how they felt this responsibility should be met. One staff member said:

Middle school is a special kind of place ... we realized that we have to service the whole child because some of the parents can't, they're not able to. We just can't focus on the intellect here, and that's just part of the whole middle school emotional development . . . that's a big part of middle school education ... just helping them through these years.

Other teachers referred to preparing students academically for high school, teaching organizational skills, and helping students to enjoy learning. When asked what influences what she teaches, one teacher commented:
What I want my students to have as background. Their futures, I think, [are] what influence what I teach. I want them to have what they need to succeed beyond me and if it means doing a lot of rote kinds of things so that in the future when they need to use that kind of information for whatever comes next, they have it.

She said that she is preparing students "for the kind of education that [she] expects them to get in high school, based on [her] own experiences at [one of the city's exam schools], which was a very academically oriented program."

If accountability exists at Stevens, it is based on "a set of tacit assumptions that teachers know what to do, that the principal knows what they are doing, and that he knows they are doing a good job." Again, when teachers are isolated and there are neither clear expectations nor accountability with consequences, teachers' responsibility rules.

\section{Hutchinson High School}

Hutchinson, a large urban comprehensive high school, is similar to Phoenix in that order prevails, but the emphasis at Hutchinson emerged from a recent history of disorder that escalated to fatalities. The teachers expected the administration "to regain control of the hallways, corridors and classrooms from the ruffians who ran wild about the building" and in return the principal made it clear that teachers were expected to take equal responsibility for "establishing a safe and orderly school environment."

Teachers at Hutchinson spoke explicitly about the importance of order and civility. Their comments about accountability and teaching, however, reflected the same ambiguity and isolation as those of teachers in similar schools. There was a formal teacher handbook, but few teachers or administrators referred to it. The teachers downplayed their accountability to the administrators. 
One teacher said: "Nobody is going to check to see what I am doing, but the headmaster will check to see if I have adequate control, whatever, more management things and techniques and that type of thing." Another teacher reported "very little collegiality," while still another said that "We impose our own standards." When asked where the standards come from, she said, "They're within us."

In addition to their responsibility to discipline, teachers described responsibility to look after their students in a shepherding manner. Nearly all Hutchinson teachers spoke of their responsibility for students' welfare, defined as, "staying out of trouble, staying healthy, and doing what's needed to graduate and either get a job or gain admission to college." One teacher said that his job was to motivate his students and show them that he cared about them.

Teachers' perceptions of their students' backgrounds are extremely important, and, when combined with lack of accountability and lack of collegiality, shift the focus to the teacher's personal responsibility. Teachers claimed responsibility for the welfare of their students both outside and inside the classroom, and spoke of being motivated by their own experiences of good and bad teachers. As at the Phoenix Charter School, when curricular standards interfered with the teacher's sense of what was right for her students, the teacher asserted her own opinion of the students' academic needs. One teacher spoke of a new standard: "There is no way in hell I will teach Algebra 2 to kids who do not understand general math! . . All students can learn, I agree with that, but I don't think they can come from middle school and be thrown into a situation where here we're setting them up for failure. Start with the first grade, keep them with us, and maybe they'll succeed."

\section{Summary}

The schools described in this section share a common solution to the problem of accountability. They delegate to the individual teacher most decisions about to whom the school is accountable, for what, and how. Accountability in these schools boils down to individual teachers' sense of responsibility. All of the schools had some proforma internal accountability systems, albeit weak ones, such as teacher handbooks or prescribed curricula. All of the schools existed within some kind of external accountability structure - charter laws, archdiocese curriculum frameworks, or local curriculum standards. But these accountability structures exercised no effective influence over individual teachers' sense of to whom and for what they were accountable.

Teachers in these schools tended to define their sense of accountability entirely in terms of their own sense of personal responsibility to what they perceived as students' needs, both affective and academic. Their responses are as notable for what they do not mention as for what they do. They did not mention formal accountability systems, which are what interests most school reformers. Instead they talked about responsibility - to their students and to themselves. They did not mention how they were held accountable - because informal or formal systems of accountability, even where they existed, had no reality in their daily lives. Regardless of recent changes in state and local accountability systems, regardless of teacher evaluations, regardless of parent involvement, even regardless of the charter school law, which is supposed to increase accountability, these teachers were still largely left to decide, based on their own values, what and how to teach.

The beliefs of teachers that exercised the greatest influence on their sense of responsibility were those related to the social backgrounds of their students. Teachers in these schools, in effect, decided on their own what kind of education was appropriate for students from backgrounds they regarded as disadvantaged. They spoke of "these children," with clear opinions as to what was required for children from disadvantaged backgrounds. The teachers stressed order in the classroom and their own conceptions of students' well-being, at the expense of academic 
performance. These views were unchallenged, either by their colleagues' expectations or by external accountability systems, because these influences were weak relative to the teachers' personal values.

\section{The Emergence of Collective Accountability: Expectations Influence Responsibility}

In the previous section, we focused on schools where individuals' conceptions of responsibility dominated collective conceptions of accountability. Our sample of schools also included schools where teachers' work was heavily influenced by the expectations of other teachers, administrators or community members. Strong expectations can influence and shape what a teacher, administrator, parent or student feels responsible for in his or her work.

In this section, we highlight three schools characterized by strong mutual expectations. The lead case in this section, St. Aloysius Elementary School, is one of the very few schools in our sample that was focused primarily on teaching and learning. The graphic representation of this school in Figure 3 highlights the prominence of collective expectations and also reflects the relationship between responsibility and expectations, due in large part to the principal's practice of hiring candidates whose teaching philosophy matched her own. St. Aloysius Elementary is a small Catholic school with a growing enrollment that is located in an affluent section of a university city. The focus on instruction is not the result of any external formal directive or accountability system, but rather the combination of a strong school leader and high expectations for students. Of particular note in this case is the way teachers project and interpret parent expectations. The assumption at St. Aloysius Elementary is that all parents have the same high expectations as those expressed by the vocal parents of high socioeconomic status.
The second case we present, North Beach High, also has a strong leader but the focus is on attainment, assuring that all students graduate. North Beach High is located in a blue-collar suburb of a major city, the demographics of which have recently begun to change from predominately Irish and Italian to a substantial Asian population. About 15-30 percent of the student population at North Beach is Asian, mostly Chinese. The third case, Tatuna Point Elementary, is a K-6 school located in the heart of an affluent suburb that is almost exclusively white and Asian. The case illustrates how powerful a force parents can be in setting high expectations for teachers and providing the support that goes with those expectations. The parental presence at Tatuna Point Elementary overshadows to a large extent the labor of teachers and administrators.

As we analyze the schools in this section, we show how expectations can shape teachers' work. In some cases the principal plays a central role, while in others the community is of more importance.

\section{St. Aloysius Elementary School}

Figure 3.

\section{$\underline{\text { St. Aloysius Elementary }}$}

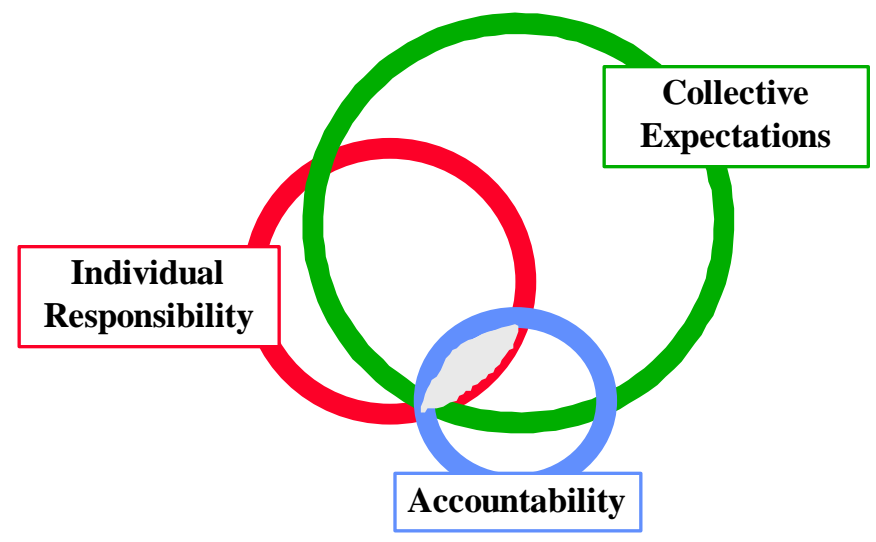


St. Aloysius Elementary serves a racially and ethnically diverse population of students in kindergarten through the eighth grade. The school has experienced a recent influx of Korean students, maintains a steady population of Haitian students, and in any given year serves several transitory European and South American students whose parents come to the region to study. About 50 percent of the students are white, 40 percent African-American and Haitian, six percent Asian, and four percent Latino/a. Less than one percent of students are eligible for Title I services as determined by family income. Seventy-five percent of the students are Catholic. St. Aloysius Elementary's teaching staff, consisting of one teacher per grade, is entirely white. By the principal's account, she has students whose parents work several blue collar jobs, and others whose parents are high-status professionals and "university parents."

St. Aloysius Elementary is Mrs. Sharp's first principalship. Since she assumed the principalship five years ago, the school has undergone an almost complete turnover in teaching staff. Only three of the current 17 staff members at St. Aloysius Elementary were there when Mrs. Sharp arrived. She attributes this turnover primarily to natural attrition through retirement, maternity leave and continuing education, but acknowledged that in some cases teachers chose to leave, having identified themselves as misfits with the school or with her approach to education. She said that at the end of her first year, "By virtue of things I said, people came to understand what I valued. And so, when some of those people left at the end of that year, I was able to hire people." She added that, "each time that's happened, I've hired someone whose sense of education and philosophy is very much in keeping with my own." While the Catholic Schools Office publishes a list of teachers available for hire, Mrs. Sharp was wary of relying upon that list because she knew of at least one person on the list who she said would be "very inappropriate" in a setting with children. She said that she is fortunate that she is given a great deal of latitude by the church pastor to hire teachers of her choice, although he has official, final authority.

All but one of the current teachers is Catholic, and the majority are young professionals with fewer than ten years' experience. Those teachers with more experience reported a good working relationship with their younger colleagues, saying that where there might have been tension, instead there was give-and-take with mutual learning. Because most teachers were hired within the past five years, several in the same year, salaries and seniority are relatively uniform across the staff. Some teachers noted that they have an unusually collegial staff and attribute this relationship partially to the fact that so many of them came to St. Aloysius Elementary at the same time and learned the ropes together. The teachers earn approximately $\$ 10,000-\$ 14,000$ less than entrylevel public school teachers in the area and many work second jobs in the evening and on weekends. Mrs. Sharp said she tries to be sensitive to their work schedules when organizing meetings or school events. She has also authorized teachers to tutor students privately after school, which she said "provides them with the additional income they need." She added that, "It's also enabled us to reach out to the segment of the community that had never been a part of our school before - the ESL children."

The school's immediate surroundings include upper-end real estate, a few shops and restaurants, and within walking distance, a large university. More than half of St. Aloysius Elementary's students live in the same zip code as the school, while the rest live in mostly suburban towns, some up to 45 minutes away. There was no playground in the small school yard at the time of our visit, but a fund drive is underway to purchase equipment. The building is well maintained, with prominent displays of student work, mostly compositions and test papers. 
Not all students who apply to St. Aloysius Elementary are admitted. If it appears that a child's needs cannot be met at St. Aloysius Elementary, Mrs. Sharp recommends another school within the archdiocese that she believes can better suit those needs, be they behavioral, academic or other. When pressed on this point, Mrs. Sharp described an informal understanding between schools, and in the archdiocese, that different schools have different missions and "for good reason." She described schools where the academic performance was not equal to that of St. Aloysius Elementary, but explained that those schools provide a real service to the inner city and immigrant communities which she perceives to have different needs.

Non-English speakers are fully integrated into classrooms at St. Aloysius Elementary. The teachers have developed informal committees to gather ESL materials and to share ESL teaching techniques. Teachers report that their classes benefit from exposure to other cultures and languages, and that they are able, though with some difficulty, to devote the necessary attention to both their native English and non-English speaking pupils.

The St. Aloysius Elementary student population is racially and ethnically diverse, but it is less diverse in terms of socio-economic background. Fewer than one percent of students are eligible for Title I services as determined by family income. Not all children come from wealthy families, but few come from abject poverty, so they are less likely than students in other schools described here to suffer the range of social, physical, and emotional risks associated with living in poverty. Unlike other schools in our sample, teachers at St. Aloysius Elementary made no reference to students' home lives or living environments as an obstacle to teaching or student learning. This is largely due to the students' predominantely middle to upper-class status, but it is also reflective of a norm at St. Aloysius Elementary that values individual responsibility for teaching and learning, and a perceived intolerance for scapegoating of any kind, even when presented with legitimate challenges to learning.

Tuition at St. Aloysius Elementary was $\$ 2,150$ in 1996-97, approximately twice that which is charged by some inner-city Catholic schools in the area. Some financial assistance is available in the second year of attendance for families meeting the school's need criteria, but the admissions process is conducted without knowledge of families' economic circumstances. When asked to describe how she believed St. Aloysius Elementary is perceived in the community, Mrs. Sharp said she and the pastor both think the school is viewed as "an inexpensive private school." She believed that many view the school as an alternative to the prestigious and expensive secular private schools in the area, and that those schools are St. Aloysius Elementary's competition.

\section{Expectations Shape Teachers' Work}

Mrs. Sharp has had relatively free reign from the church pastor to exercise discretion in hiring staff and managing the school budget. Mrs. Sharp was very happy with her current teaching staff and described them with terms such as "professional," "skilled" and "collegial." When asked what she looks for in new hires, she said that they should believe "all children can learn, [and be someone] who looks for the ways in which they learn and will have a multiplicity of activities ... a person of good will and values. "

She attributed much of the coherence within the school to having hired people whose philosophies of teaching matched her own, but was quick to say that she was not a directive principal, and that the staff has developed into a cohesive group largely on its own. As an example, Mrs. Sharp said that the teachers requested that one of the four faculty meetings per month be devoted entirely to collegial discussion related to curriculum and pedagogy. She also noted that last year, the staff agreed to seek additional accreditation, beyond that awarded 
by the archdiocese, because they knew they could get it and because the coherence and academic quality it required "would appeal to people looking for a good school for their children."

Without exception, teachers described an atmosphere of high expectations at St. Aloysius Elementary. Some stressed a high priority on "reaching every child" and "making sure no one is left behind," while others referred to a serious and supportive environment where everyone is expected to put forth excellent work. Teachers did describe a range of abilities within their classrooms, and the particular challenge of teaching ESL students, but none referred to this as an obstacle to teaching. Rather, they described a school culture where teachers are expected to improvise and to "reach everyone."

This belief in high expectations for all children applies to both academic and social learning at St. Aloysius Elementary. Academically, children are expected to achieve at the highest level possible for them. Teachers said, with varying degrees of certainty, that they believed every student can learn the skills taught at their grade level, and in many cases students exceed those expectations. When asked if all of her students could learn the skills expected of their grade level, one veteran teacher responded: 'If I see they're having trouble, I'll tutor. They're given the time for help. We just stay with it until they know it." She continued, "I never worry [about them going to the next grade] because they always know what they're doing." These comments reflect the teacher's philosophy, and her expectation that students will "stay with it" too. Students praised this particular teacher for her willingness to give extra help, for her unbending belief in them, and for her equally unbending expectation that they will learn and retain what she teaches them.

Teachers recognized that students have varying ability levels, and they described the challenges they face in teaching ESL students, and that these students face in learning. The teachers maintained "high expectations" for the ESL students by insisting on the highest degree of effort while, in some cases, adjusting performance expectations. For example, the fifth through eighth grade teachers developed an ESL program that defined what teachers expect of their non-English speaking students. One teacher told us: "We expect them to increase their English understanding and comprehension of English. We expect them to maintain math skills and improve. We listed a set of criteria that we're going to expect from ESL students."

Student report cards in the upper grades at St. Aloysius Elementary have a column for performance and another column for effort. There is no effort column in the lower grades, but teachers write comments which include a description of student effort, behavior and progress. Only one teacher described occasionally inflating letter (or number) grades based upon student effort or extenuating circumstances that might be particularly challenging for an individual child.

When asked how they were able to maintain high expectations for all children, despite the range of student abilities and preparation, several teachers said that they did not expect identical work from every child, but performance grades accurately reflected the range in student products, and effort grades (or comments) focused on the expectation that every student do his or her absolute best. Although not every child can produce exemplary work, those children putting forth their best efforts can be rewarded with an "A for effort." Teachers indicated that students were not graded in comparison with one another, or on a curve, but often on the basis of rubrics. One example of a rubric was a scoring sheet the teachers developed for the Science Fair. Students first received an information sheet explaining what was expected of them. Several weeks later they received a sheet stating that their topic would be due on a certain date, and their outline due on another date. Finally, they 
received the actual scoring sheet that listed all the criteria upon which they would be graded.

Most faculty members assumed students would finish high school, some of them graduating from prestigious high schools, and that the "vast majority" would go to college.

When asked what parents expected of them and the school, teachers responses seemed to place equal emphasis on instilling Christian values and on challenging the students. One teacher, comparing St. Aloysius Elementary to another school where she taught, commented:

[The previous school] was much more working class, very few of the parents had gone to college and education was not number one on everybody's list of priorities. . . Whereas here, I think people really respect your pushing their kid to do their best and I like that . . The students are much more motivated [here]. The parents are much more supportive ... and the students, quite honestly. . . my students seem to be smarter and more interested in doing well and living up to the expectations that I have set for them, they have set for themselves, that their parents have set for them as well.

Another teacher described the school as being in the business of "educating the whole child," and said that parents expected that teachers would be there before and after school "modeling that philosophy" for the students.

Several parents verified this assessment of parent expectations. One parent said that she worried, at first, that the school might be too much pressure for her son, but that she's discovered he thrives in the "challenging environment." Other parents of younger children expressed a desire to get their children an "early start on their education," and in an environment that is disciplined and orderly.
When asked what parents expected, Mrs. Sharp remarked:

I think all the parents are setting high expectations even though some of them may not be able to articulate them very well. I feel very strongly that they all want high academic expectations for their children. They all want their children to be good human beings. . . There is a group that will voice that more strongly than many others will and so yes, we do respond, we hear them and we consider how we're going to respond to them. For the parents who may be less able to articulate expectations or maybe less aware of the quality of education that is being provided to their children, I think they recognize there's something special. I try to deal with the parents on an individual basis, as opposed to a movement . . We have our parking lot brigade here, we have a few parents . . I've got a few teachers here that are very adept at diffusing that. The very unity of our philosophy helps that.

The parents we met in a focus group described a variety of expectations for the school. Some of the parents' expectations focused specifically on teachers, but overall, they seemed not to differentiate individual people's roles. One father said:

I guess I certainly expect the school to educate. You know, academic education is certainly what they start out with, and the school seems to do that well. And the only way that can happen is if the environment in the classes allows the children to do that and I think that comes from the expectations that the teachers have of the children and I think that is a difference that seems to ... that is a difference between this school and some of the public schools that I've heard kind of anecdotal talk of. In some of the public schools, some of the 
kids seem sort of lost somehow. And that doesn't seem to happen so much here at [St. Aloysius Elementary].

Parents also described wanting frequent communication from teachers and the school, and wanting the school to be responsive to their children's individual needs. They remarked that teachers at St. Aloysius Elementary do not teach the same lessons repeatedly, but seem to vary their teaching. Parents noted that the teachers continue their own professional development, something the parents valued and expected, and believed to distinguish St. Aloysius Elementary from public schools. Teachers perceived that parents have high expectations of them and of the school.

Speaking to the question of expectations of teachers, and the school as a whole, a parent who was highly involved in the school commented on the effects of social-class, and proximity to the university:

The higher the level the parent educationally, the higher level the child will reach ... the parents are going on to post-graduate work and then they're expecting at least their children will get to that level and I do think it lifts the place ... I think it is a very good influence on the school that that's there. It's like strings from above pulling you up.

This comment speaks both to the way parents at St. Aloysius Elementary were perceived by staff, and to the expectations those parents communicated in various was to the staff.

\section{Teachers' Sense of Responsibility Reflects Expectations}

The staff at the school responded to what was expected of them by the principal, parents and their colleagues. Those collective expectations affected teachers' personal sense of responsibility.
Their sense of professional responsibility was largely informed by the schools' collective interpretation of its community's needs and expectations.

Without exception, St. Aloysius Elementary's teachers expressed feeling responsible for the learning of every individual child, and for maintaining high expectations for all children. Everyone described feeling responsible for their students' social development. In some cases this was characterized as religious teaching and in others as training in good manners and behavior.

When asked for what she felt responsible, one teacher responded definitively:

Well first, academics. To make sure that the child is learning what they should be learning. That they are on level. If they are above level, that they're being challenged. If they're below level, that they're receiving the extra help they need. As far as, like, socially, teaching them the right and wrong... Even though not everyone is Christian, you're teaching them about God and loving each other and working together. So, I want to develop them . . My responsibility is to develop their mind, academically, develop their soul or spirit, morally, and [help them] to be able to survive in life.

A first-year teacher's comments about her personal sense of responsibility cover most of the points raised by her colleagues:

I feel that I am responsible for teaching them the tools so that they are accountable, so that they are responsible for themselves, their work. I think I'm responsible for setting a high level of expectations so that they know that's what they're expected to meet, so that I don't accept mediocre work. I definitely feel responsible for that ... for setting a tone in here that's serious yet light-hearted enough that they feel comfortable enough to interact 
with me and they're not scared of the teacher. Ifeel responsible for sending home information so their parents are up to date as to what's going on exactly in this class every day. Ifeel responsible for them going home every day... and knowing what they've learned so that they can't say, "nothing" when their parents ask because they know [my] ears burn even if I'm millions of miles away.

Several teachers described doing whatever was necessary to help a child learn to his or her full potential- "to do the best that he or she can." Some teachers implied that they "just get to know" students' abilities and work habits, but no one offered an explicit explanation of how they gauge a student's potential, or what is his or her "best."

Those teachers who said they felt responsible for "individualized learning" and "educating the whole child" explained that this means making oneself available to students for extra help before and after school. Others emphasized teaching children with varying learning styles differently. When asked to expand upon this idea, one teacher made a clear distinction between students whose grades suffer because they do not do their work, and those who "don't get it" and do poorly on tests:

... if you're choosing not to turn in your homework, not to do your assignments, I think the responsibility falls on you [the student]. If test grades are the big problem, I think sometimes I'd look to me. Why isn't, if half the class is not understanding what's on the test, that's my fault I think. And then I'd look at how I was teaching or what I was neglecting to teach or what was the method I was using that wasn't reaching half the class.

We asked teachers what responsibility they felt to compensate for problems students might experience out of school, at home or in their communities. The teachers indicated that this was not a big issue at St. Aloysius Elementary, but described sensitivity to such problems as part of their jobs. Examples offered usually related to marital problems between parents, or parents whose work schedules prevented them from being as involved with their children as other parents. They implied a willingness to address children's social, emotional or physical well-being as part of their "whole child" orientation, but they clearly did not view themselves as solely or primarily responsible for these non-academic areas.

\section{Other Schools}

\section{North Beach High School}

North Beach High School has just over 1,200 students and is located in what one teacher called an upwardly mobile blue-collar community. The majority of the student population is of Irish or Italian descent. About 25 to 30 percent of the students are Asian, mostly Chinese, who have proficient language skills; high school students who are not proficient in English attend the other high school in town. The school operates as one large family. As one respondent said, "It's like a big family, you know, and I think a lot of things get done sometimes based on relationships as opposed to a structure." In interviews, two teachers identified the principal and assistant principal as the "mother and father" of the school. Many of the 175 adults who work in the school are graduates or parents of graduates - both the principal, assistant principal, and three deans graduated from the school. North Beach High School teachers and administrators grew up together, attended the same schools and churches, and shared cultural traditions. Membership in this close-knit community includes a sense of obligation to take care of all of its members. In the case of schooling, this means that children will graduate from high school.

North Beach High School is committed to seeing that all students graduate and, essentially, does not let any student drop out. The assistant principal explained, 
"Basically, we hang onto kids forever ... we work with the one to two percent who drop out, we work with them forever and we try and try ... because we're going to pay now or later." The principal added, 'I'd like to have a dollar for every kid who dropped out of school and who came back and earned it." North Beach High School reports a drop out rate of 1.3 percent. The assistant principal was concerned because it had "creeped up" from 1.1 to 1.3 percent. She said that she would "even violate the attendance policy on the side of kids" to keep the them in school. The student advisor system is tied into the homeroom structure and assures that one adult consistently touches base with every child each day of his or her high school years. Students have the same homeroom teacher for four years. The homeroom teacher goes to graduation and gives their homeroom students their diplomas.

The school administration is more laissez faire on instructional issues. The principal had confidence in the subject knowledge of his teachers and expected them "to perform their best, realizing they're all different-different personalities, different vocabularies sometimes ..."

\section{Tatuna Point Elementary School}

Tatuna Point is an elementary school, located in a relatively affluent suburb, where academic expectations are high and student achievement is taken seriously. Second graders talk about going to Ivy League colleges and teachers know that is what many parents expect. As one lower grade teacher explained, “ . . . standards are very high academically; it's expected by the parents, the community, and the staff, and we work hard to meet those expectations." Parents are involved in almost every aspect of the school. Parents are vocal about expressing demands, and they are active in providing support for what they demand. Parents know how to articulate their demands loudly and are ready to take the steps necessary to achieve themwhether by voicing their discontent to teachers, administrators or district officials, or by organizing and participating in formal institutions that control and regulate school activities. As one parent said:

There's a lot of parent involvement . . . Parents are willing to be very vocal and express their concern, or shall we say "whine." Most of the parents, because they're highly educated, put a real premium on education, and therefore expect a lot from the schools... expect high performance from the schools, and therefore make a lot of demands on the staff, on the principal, on the curriculum. But on the other hand, the majority of those parents say, "I want this, but what can I do to help you get it?" . . . My take is that they're willing to back up their demands, if you will, with support, either financial or hands on.

The parents do in fact back up their demands. According to the principal, last year the PTA counted over 8,000 hours of volunteer time, not including those who forgot to sign in. On any given day, parents can be found assisting the school secretary, working in classrooms, shelving books, staffing the computer lab, or helping coach a sport or other activity. The PTA donates $\$ 50,000$ yearly in capital goods such as playground and computer equipment. In 1991, a group of parents established the Tatuna Point Elementary Educational Foundation, a non-profit foundation dedicated to raising funds to provide additional resources for the improvement of the quality of education. Each family at the school is asked to make a cash contribution of $\$ 350$. Approximately 40 percent of school families give to the Foundation. The funds have supported additional teachers, consultants, and classroom aides. Students at the school also raise money through an annual walk-athon sponsored by the Foundation. Parents are also very active on the school council. The principal explained, "The Foundation buys people, the PTA buys stuff ... and the school council keeps it all coordinated and going together." This parental effort overshadows the work of the teachers. One parent 
noted that as a newcomer to the school, she heard much about the parents - the PTA, the Foundation, and the site council—but very little about teachers.

Despite the school's academic program and relatively high performance levels, parents at Tatuna Point Elementary questioned whether their children were sufficiently challenged academically. Parents were frustrated by what they claimed was a lack of individualized attention. As one parent explained, “... the teacher [ought to] get to know each child and know how to deal with each child separately instead of expecting all thirty-two to do the same thing." Most parents were confident in what they believed was best for their child's education and would exert their influence in the classroom, in the principal's office or at the district level to ensure that their child benefitted from a high-quality education tailored to the child's particular needs. The principal explained, "They know how to use the system. They know how to access the system ... If they didn't like what I did, they know who to go to. They know who is my boss. They're not shy about calling the superintendent if they have a problem."

The Tatuna Point Elementary Education Foundation has been instrumental in getting classroom aides for the lower grades. The aides are closely monitored by the Foundation's board of governors. The Foundation, the school site council, and some independent parents conducted an evaluation of resource teachers and classroom aides to assess whether students received more individualized attention as a result of the increased support. Teachers were requested to keep a log of aides' time every day for one week and classrooms were formally observed by a team of parents. The evaluation report stated, "In the primary grades, 77 percent of aide time was spent working with small groups or individual students and 23 percent was spent in clerical duties. In the upper grades, 38 percent of aide time was spent in working with small groups or individual students and 62 percent was spent in clerical duties." Parents found the upper-grade condition unacceptable and requested that the principal discuss the issue with the upper-grade teachers to assure that classroom aides were used more appropriately. One teacher explained if they pay for the aides, they can dictate how we use the aides. The same teacher summarized the parent sentiment by saying, "We're not going to fund it unless you're doing it our way."

Parents also disagreed with the local district's opposition to tracking students according to ability. There are gifted and talented classes but they are limited to the top two percent of children. Parents were frustrated by the limited available space and felt that their children remained in a system designed for "less able" students. Parents at Tatuna Point often bypassed the school leadership to go directly to the district to assure their children's placement in the accelerated program.

Although teachers appreciated and welcomed the participation and support of parents in classes, and valued the additional resources they brought to the classroom, they also resented when parents made determinations about how teachers should do their jobs. The parent activism was certainly felt by the teachers and the principal. Teachers knew that if they were not doing what parents expected, they would hear about it, either verbally or in writing, by way of the principal or even the superintendent. One upper-grade teacher commented, "I think my greatest pressure comes from the parents and from what they're asking of me or what their expectations are of me." The same teacher said, "I am happy when I have no parent letter in my box."

Teachers at Tatuna Point worked long hours and the work was certainly influenced by the demands of parents, whether expressed directly or through the principal. In spite of outside pressures from parents, district requirements or administrative mandates, the teachers still asserted that their actions were first and foremost driven by what they viewed as the children's best interests. The teachers did appear to do what was expected of them, but the principal argued that they did so 
from self-motivation and personal dedication. As the principal explained, "The accountability structure here is very often self-imposed by the teachers."

\section{Summary}

The schools in this section demonstrate a different solution to the problem of accountability. The first group of schools essentially turned all accountability problems into matters of individual teacher responsibility. These schools have all developed, in somewhat different ways, a relatively powerful culture of expectations that shapes individuals' views around a common purpose. These schools operate without highly visible internal accountability structures, but they accomplish many of the same purposes through expectations. At St. Aloysius Elementary, Mrs. Sharp has been highly influential in constructing a community of teachers, students, and parents focused on academic learning, largely through the influence of strong expectations. At North Beach High School, the culture of common expectations comes from both the school leadership's ethic of a "family" environment, and from the cohesive culture of the local community which is transmitted to the school through the staff, who are natives of the community themselves, and graduates of the school. Expectations at North Beach are focused mainly on attainmentgetting students to stay in school and to graduaterather than on academic learning. The expectations at Tatuna Point Elementary seem to originiate largely from aggressive and demanding middle-class parents who pressure teachers and administrators, the latter see themselves as somewhat beleaguered but heavily influenced by these parental expectations. The expectations of parents in Tatuna Point Elementary are beginning to translate into an incipient accountability structure evolving in the Foundation's strong influence over the expenditure of its funds.

In all three cases, collective expectations exercise a heavy influence on teachers' individual conceptions of their responsibilities. Mrs. Sharp deliber- ately selects teachers who share her views that all students can learn; the teachers at St. Aloysius Elementary share a view that de-emphasizes family background as a determining factor in student learning, instead emphasizing student and teacher effort. At North Beach High School, collective norms about the custodial role of schools and the importance of attainment heavily influence the way teachers think of their work with students. And at Tatuna Point Elementary, teachers internalize the norms of competitive academic achievement or risk the disapproval of parents.

\section{Internal Accountability: The Alignment of Responsibility, Expectations, and Accountability}

In the schools we have examined so far, individual conceptions of responsibility and collective expectations tend to guide the actions and motivations of teachers. These factors appear to operate in a way that is incidental to any formal arrangements or consequences that are visible within the school. Teachers may feel responsible for maintaining order in classrooms and hallways, and this sense of responsibility may be translated into shared expectations, for example, but in many schools there are no visible arrangements for enforcing this obligation and little in the way of direct consequences for failing to meet those expectations.

In this section we discuss three schools in which a strong internal accountability system has emerged, which appears to influence the actions of members of the school community. These three schools operate within quite different external accountability policy structures, yet within each school, teachers (and parents in the case of one of the schools) are held accountable for meeting a set of shared expectations. Regardless of the differences in the external policy structures, in these schools accountability is a strong internal operating principle. 
We consider how expectations can shape an internal accountability system within these three schools. While not a formal external policy mechanism, the internal accountability system appears to strongly influence teacher behavior, and corresponds closely with teachers' understanding of their personal responsibility. Unlike these discussed previously, the schools discussed in this section are characterized by visible accountability structures with consequences for failure to meet set expectations.

These schools illustrate the idea outlined in our working theory that internal accountability systems are likely to influence individual actions if they are closely aligned with individual responsibility and collective expectations. These three schools vary in the content of their shared expectations, but they are similar in that the alignment of personal responsibility with shared expectations, combined with some consequences, has led to an internal accountability system that actually affects actions and behavior.

The internal accountability systems in these three schools appear to have the greatest impact on behavior, but they still operate within an external policy structure. The degree to which the external policy structure affects behavior appears to be related to the degree of alignment between the external policy and the internal accountability system. If there is a conflict, the internal system appears to have a greater influence on behavior.

The lead case is Turtle Haven, an urban pilot school, locally-chartered elementary school, serving a high proportion of minority and disadvantaged students. Turtle Haven demonstrates the emergence of internal accountability in an environment of shared expectations for high-quality academic work, as represented by the high degree of alignment in Figure 4.

Saint B's is an urban Catholic elementary school, serving a predominantely working-class student population. St. B's demonstrates an internal account- ability system extended to include parents. Pine Creek, an urban elementary school serving predominantely poor white students, demonstrates the alignment of responsibility, expectations, and internal accountability around relatively low expectations for student academic work.

\section{Turtle Haven Pilot School}

Figure 4.

\section{Turtle Haven Pilot School}

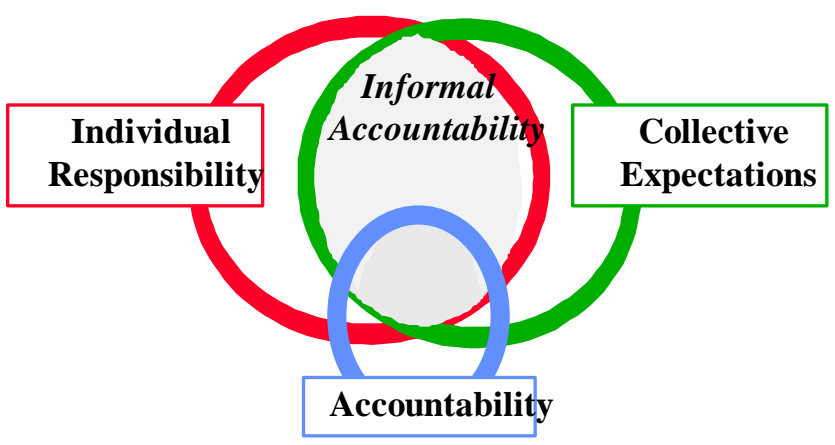

Turtle Haven Pilot School is a small elementary school located in a low-income community in a large eastern city. As a pilot school, or a locallychartered school, Turtle Haven is administratively affiliated with an urban school system of over 60,000 students, but exempted from many of the district regulations. The building itself is not owned by the school district - the school is housed in an unused wing of a parochial school. The building is old and in disrepair, but the display of student work in the hallways and classrooms livens up the atmosphere.

Although located in an old building, this is a brand-new school, only in its second year of operation. The city's pilot schools were founded as part of an agreement with the local teachers' union in an effort to provide models of excellence which would spread to all of the city schools. Pilot schools are expected to be "models of innovation," and their advocates believe they will lead to improved student 
performance in other city schools. Because pilot schools are expected to provide models for other city schools, the models are supposed to be replicable system-wide, although the city has no formal plans for replication.

The Turtle Haven Pilot School was originally promoted for its "technology-based curriculum, active parent participation, and individualized instruction." The school opened with grades K1(a readiness class for four-year olds), K2 (the second kindergarten year), first grade and second grade, then during its second year expanded to include third grade. The school also operates an extended-day program, providing after-school services for children until 5:30 in the evening.

There are currently 200 children enrolled, 57 percent of whom are eligible for free or reduced meals. Turtle Haven participates in the city's choice system, and as a result, students are bussed from many different parts of the city. About 65 percent of the students are African-American, 25 percent Anglo, nine percent Latino/a, and one percent Asian and Native American.

The classrooms at Turtle Haven have many similarities. Desks are arranged in clusters of four or five. Each room has a meeting area with a big blue gym mat on which children sit. In each classroom, the teacher posts a morning message — a handwritten greeting outlining the day's activities. Children appear to be actively engaged in work, frequently working on different projects at the same time. Most classrooms are not quiet, but the noise appears to be the productive sound of children working.

As a pilot school, Turtle Haven is exempt from union regulations governing the hiring of staff. Hiring is conducted directly at the school site, and as a result, the staff characteristics are somewhat different from those of a typical city school. Many of the teachers are young-in their midtwenties-with little prior teaching experience. The teaching staff is diverse, with six African-American teachers, six Anglo teachers, two Latino teachers, and one Asian teacher.

\section{External Context}

Turtle Haven has a unique external accountability context. Having been granted a pilot status, the school is evaluated every three years, and in theory can be closed if it has not met the goals of the pilot school initiative. It is not yet clear how such evaluations will work. Staff at the school expressed confidence, however, that whatever evaluation mechanism is used they will certainly meet and exceed the district's expectations. The threat of losing pilot school status did not have a strong influence on the teachers' understanding of accountability. In this way, Turtle Haven is similar to Phoenix Charter School in that the accountability arrangement under which it operates is not a heavy influence upon conceptions of accountability, insofar as it offers greater freedom from accountability.

Turtle Haven also operates within the context of district-wide mechanisms designed to hold all city schools accountable. Since hiring a new superintendent, the district has embarked on an ambitious systemic reform initiative-several components of which relate directly to accountability. For example, this reform includes the implementation of "Citywide Learning Standards" which outline specific expectations for each grade level. Children must demonstrate performance in relation to the standards by creating the "products" designated for each grade level. These products are performance-based projects directly related to the objectives of the learning standards. The district also administers the Stanford 9 achievement test each year. This test was selected because it was most closely aligned to the learning standards.

Although the district has developed standards and designated products, it is still not clear to teachers how these products will be used to judge a school's success. Most of the teachers at Turtle Haven were 
working to help all students meet these standards, but they were unclear whether or not the district would collect the products, and if so, how the district would evaluate the products. The district has not provided schools with a detailed rubric by which to evaluate the products, so it is difficult for teachers to determine "how good is good enough?" when evaluating student products. This confusion was not unique to Turtle Haven, but common among the public schools in this district included in our sample. Turtle Haven differed from other public schools, however, in its efforts to incorporate the standards and products, vague as they were, into the school's self-generated academic program.

Nor was it clear to teachers how standardized testing would be used to hold schools accountable. Several teachers did mention that they felt accountable for student performance on these tests, but others said they felt more accountable to parents than to the district for a student's test performance. One teacher explained, "Formal assessments, like the Stanford 9, parents want their children to excel on those types of tests. We don't teach to the test, but we have to be accountable for how the children do on the test."

The district has begun to design mechanisms for holding schools accountable, but these mechanisms are not yet visible at the school site level. There are very few rewards and sanctions that recognized a school's performance. Therefore, we characterize the external accountability context as relatively weak. Within this weak external accountability structure, however, Turtle Haven has developed its own internal accountability system with a strong set of expectations closely aligned with personal responsibility.

\section{Expectations}

They (expectations) taken together create sort of a school culture ... that's very defining and distinctive and says, this is what we're about. (Turtle Haven teacher)
Turtle Haven's principal, Mary Carter, has made a very deliberate effort to make her expectations clear to teachers. It is no coincidence that classrooms look very similar. At the beginning of the year, she distributed a list of "components or things" that should be found in every Turtle Haven classroom. This list included physical objects, such as a morning message board and student work posted on the walls, and activities such as choice time and morning meeting. In this document, she outlined her expectations about parent involvement. Each teacher is expected to hold four family events during the year, and 100 percent attendance is expected. Teachers must also hold parent conferences and communicate regularly with parents by letter and phone.

Interviews with Turtle Haven teachers indicated that most of the staff have internalized these expectations and make every effort to live up to them. The responses of most teachers regarding the principal's expectations closely matched what the principal told us are her expectations. Several teachers listed expectations that repeated the written guidelines Ms. Carter had presented at the beginning of the year. Among the expectations they believed Ms. Carter had, teachers mentioned choice time, use of the Responsive Classroom model, morning meeting, and planning successful family events.

One teacher, after listing many of the expectations outlined in Ms. Carter's written guidelines, explained the importance of these clear expectations. She referred to the "components or things" as:

Structures that support expectations we've agreed we would have. I feel that's important. It's one thing to say, theoretically, it's your job to involve families. It's another thing to say, here's a way we expect you are going to do it, which is to have a certain number of classroom events. That makes it concrete and makes it so it's clear. 
The specific expectations noted by the teachers appear to be directly connected to Ms. Carter's broad and general expectations of teachers and the learning experiences they provide for their students. On this subject, Ms. Carter commented:

One thing is around curriculum development and being able to construct a learning environment that engages all children, that allows children to grow and develop and learn in ways that . . in creative ways, in thoughtful ways, in ways where the teacher can take on a lot of different roles. Not just standing and giving information, but being a facilitator and this sort of person that guides their understanding.

In addition to this expectation of academic student-centered instruction, Ms. Carter also mentioned the importance of a social curriculum and community-building. All teachers were expected to use the Responsive Classroom model, and were provided with the necessary training.

Ms. Carter sees community-building as her most important responsibility as a principal. She explained,

What's most important is instructional practice and curriculum, but before that is community, is building community. A very significant learning community. But then everything else falls under that ... I see my work as a principal as being more of a community activist, and more of teaching children what is possible in healthy communities than what is already existing. Giving them another model, another context in which to see the world, and which to see themselves.

The teachers' understanding of these general philosophical expectations appeared to be closely aligned with what Ms. Carter told us. For example, when asked what Ms. Carter expects of her, one teacher responded, "You are expected to think about how what goes on in your room emanates from kids' interests." Other teachers responded that teachers were expected to "teach in a meaningful way, and to have high expectations of kids and to teach social behavior too." One teacher said Ms. Carter thought that, "the social curriculum is on equal footing with the academic curriculum." Several teachers referred to the expectation that they use the Responsive Classroom model. One teacher explained the model's emphasis: "Teaching kids how to listen to each other, how to ask questions, how to be kind, how to be helpful, how to be responsible, and that's a huge part of the day."

Teachers at Turtle Haven work in an environment of clearly articulated administrative expectations. The expectations are communicated through writing, through informal conversations, and during staff meetings and professional development activities. Our observations in the school and interviews with teachers revealed that most teachers made every effort to align their teaching practice to these expectations.

Ms. Carter has clearly articulated her expectations for pedagogical practice and technique. She also has expectations related to the expectations the teachers have of their students. Although the school works with a large percentage of poor and minority students, a population for which other schools in our sample set relatively low standards, the teachers at Turtle Haven believe that all children are capable of learning at high levels. Teachers in other schools we studied explained low student performance by arguing that "these kids have so many needs, it is more difficult to teach them." We did not encounter this argument at Turtle Haven.

Ms. Carter explained her expectations for student performance:

I have higher expectations (than the City) ... When I first came to [City] and I looked at the standards the teachers were using, I was appalled. I mean I was really... This was 
before the new standards came out. So I took the standards from [Neighboring City] which I thought were more comparable to what my thinking around what kids should be able to do in first grade and used those. Yes, I think my expectations for learning are higher in general for students not just in first grade, but in general. I don't look at a child and assess what they're capable of. I feel like so much of that goes on in [City].

Teachers at Turtle Haven appeared to mirror Ms. Carter in her philosophy about expectations of students. All teachers strongly resisted the belief that children from disadvantaged families and communities were less likely to succeed. At a meeting with the entire school staff and the researchers working on this project, the teachers were asked the source of their expectations for children. One teacher referred directly to Ms. Carter's conviction that all children are capable of great things, and mentioned that this belief leads teachers to challenge all students. At this same meeting, two Turtle Haven teachers spoke strongly against the tendency in inner-city schools of characterizing families and communities as the source of the problem. One teacher called this characterization "vindictive and victimizing" and enabling educators to make excuses. Another teacher said, "Inner-city kids do not need to be saved, they need to be treated fairly and with respect."

\section{Expectations Influence Responsibility}

In this context of strong expectations, how do expectations influence or work in conjunction (or conflict) with individual teachers' sense of personal responsibility? Unlike schools discussed earlier in this report, Turtle Haven appears to have a close alignment between personal responsibility and the principal's expectations. In some cases, it seems Ms. Carter's expectations shaped an individual's understanding of responsibility, while in other cases, it appears that Ms.
Carter has hired teachers who already possess a sense of personal responsibility that is closely aligned with her expectations.

For example, many teachers mentioned feeling personally responsible for their students' social development. One third grade teacher, when asked for what she felt responsible, referred to many "study skill" related areas-helping children to develop the ability to work independently, and to develop their confidence and listening skills. She also mentioned a responsibility for teaching students to respect each other, cooperate and respect adults. Although she mentioned that these were school-wide expectations, she also felt very responsible for them personally.

In this example, there was a clear alignment between the teacher's sense of personal responsibility and the expectations outlined by Ms. Carter. Another teacher discussed the importance of such an alignment: "Not that we're trying to prove something to make Mary pleased, but that we really believe and we buy into the practice that all children can and will learn if you set the stage, and you set high expectations. And if these are your ideals, not rhetorical ideals, that you believe in, you have a place here."

This alignment within the Turtle Haven school was also apparent in the case of the one teacher who saw a conflict between her sense of personal responsibility and Ms. Carter's expectations. This particular teacher saw her philosophy of teaching as more traditional than that of Ms. Carter and the other teachers in the school. She believed that:

Before they're allowed to go, they should be given the basic steps . . to have self-control to be able to know that,... . I have something to do. I'm going to take my time to read the directions. Do I understand?' Like if I set up centers and let them move through centers, they have to know that at the end of a certain amount of time ... these things have to be turned in. And my class just isn't there yet to 
just go at centers. And I'm viewed as being very traditional because of that. In terms of behavior, I really feel that there should be control in the classroom. I can't teach if everyone is talking at one time.

\section{Consequences: What Happens When You Don't Meet Expectations}

For the teacher quoted above, there was a conflict between her personal sense of responsibility and the expectations set by Ms. Carter. For alignment between expectations and personal responsibility to function as an internal accountability system, there must be consequences if the alignment does not exist or if an individual fails to meet the expectations. For this particular teacher, this lack of alignment led her to leave the school. This decision appeared to have been made jointly by the teacher and Ms. Carter. Ms. Carter explained the decision, "That was a meeting of the minds. And it's a good leaving. It's a good leaving because it's not a good match."

The teacher explained:

I'm told that I'm too traditional, that I expect the kids to sit too much. That they're used to being out of their seats and that they should have more choices, more choice time. So, that was the decision we came to since we don't have the same philosophy. That we would just let it go.

To understand how consequences transform expectations into an informal accountability system, we asked several teachers the following question: "What happens at Turtle Haven if teachers do not meet Ms. Carter's expectations or conform to the school culture created by those expectations?" Most teachers believed that a person who did not meet expectations would first receive a great deal of support from the principal and other colleagues. Teachers seemed reluctant to say if such a teacher would eventually lose his or her job. Most agreed, however, that a teacher who did not meet the expectations would not be happy at the school and would eventually "try to weed themselves out" of the school. As one teacher explained,

The administrator would initiate a lot of support kinds of structures to try to help that person meet expectations, and that's something that would go on for a long time. Eventually, if things were not able to come together and there was a sense in the community that a certain number of children were not able to get the kind of education that we say we're committed to providing, then I think at a certain point the issue would be, we have to think about whether somebody belongs here or not.

Ms. Carter was less reluctant to describe the process by which she addressed the issue of teachers not meeting her expectations. We asked several questions about what would happen if a teacher did not meet the expectation regarding parental attendance at the four family events.

Ms. Carter: I would say if you've tried everything, if you've truly tried and you put all those things in place. You gave them enough time, you did the calls and all that kind of stuff, you tried different times of the day. There's a lot that you would have to be doing. Then I would be very concerned about the teacher. I would be very concerned. And that's happening as we speak.

Interviewer: Are they going to be back next year?

Ms. Carter: Right now, if I had to decide today... No. And that's what the teacher's been told. No. 
Ms. Carter explained that deciding to let a teacher go is one of the most important decisions she makes as an administrator:

I don't feel there are a whole lot of decisions that I make alone in this school, But my job is to identify the best educators for children. And to hold every teacher accountable for high-quality work for kids and families. And it can be done. I don't accept a whole lot of excuses.

\section{Internal Accountability}

At Turtle Haven, the principal has established a strong set of expectations that guide teacher behavior. These expectations are both grounded in an educational philosophy and relate to specific pedagogical practice. In some instances these expectations shaped personal responsibility in teachers, while in other cases it seems that individuals were hired because their sense of personal responsibility matched Ms. Carter's expectations. The autonomy in hiring at the pilot school has been crucial in building this alignment between expectations, personal responsibility and internal accountability, although we did not observe this alignment uniformly across the charter schools in our study.

In the few instances where there was a conflict between personal responsibility and administrative expectations, or where a teacher was ineffective in meeting expectations (even though she may have felt responsible for similar goals), the functioning of the internal accountability system was clear. There were consequences for teachers who failed to meet the expectations that had been established. Consequences connect expectations and personal responsibility to shape an internal accountability system at the Turtle Haven Pilot School.

\section{Other Schools}

\section{Saint B's Elementary School}

Internal accountability does not necessarily affect teacher behavior alone. At Saint B's Catholic School, we saw how strong expectations, established by administrators and teachers, aligned with personal responsibility on the part of parents, created an internal accountability system designed to hold parents accountable for involvement in their children's education.

St. B's Catholic School serves 600 students in kindergarten through grade eight. The school is located in M-town, an incorporated city affiliated with one of the largest metropolitan areas in the country. Residents of M-town are mostly lowermiddle class. Admission to St. B's is competitive. Before being admitted to kindergarten, students must take an admission test that evaluates their fine motor skills and knowledge of letters, colors, shapes and numbers.

The school is operated by the St. B Catholic Parish, and the parish pastor, Father L., is ultimately responsible for the school. In practice, however, it is the school's principal, Sister A. who makes most of the decisions for the school. Like Turtle Haven, the school operates within a relatively weak external accountability system. The school is a member of the archdiocese of the metropolitan area, but archdiocese officials emphasized that their influence over St. B's was only advisory, and that the archdiocese officials had no direct authority over the school. Despite the advisory nature of this relationship, however, both the school principal and many parents asserted that the archdiocese in fact does have control over the school.

The most direct way in which the archdiocese influences St. B's is the "scope and sequence" curriculum. Teachers are expected to cover this curriculum in their classrooms through the course of the year. The archdiocese also receives financial reports from the 
schools and publishes guidelines on a variety of issues including safety, governance, and curriculum. Despite these guidelines, archdiocesan officials insisted that St. B Catholic School may not be ordered to follow these guidelines, although it is expected to do so, and usually does.

Within this external context, St. B Catholic School has developed mechanisms for ensuring that external guidelines and internal expectations are met. For teachers, these expectations are generated primarily by the principal, Sister A. All of the teachers interviewed for this case study described their performance in terms of Sister A's expectations. She visits each classroom weekly to inspect lesson plans and to review the students' agenda books (pamphlets distributed to all students which include school rules and other relevant information and have weekly calendars with space for students to note their assignments). In addition to these weekly walk-throughs, Sister A also evaluates all teachers annually using a standardized format including formal observation and a written report.

These internal mechanisms at St. B's exist to hold teachers accountable; more striking are the structures designed to hold parents accountable. At Turtle Haven the internal accountability system worked to hold teachers accountable for parental involvement, but at St. B's, parents are held directly accountable for their involvement in school activities. As a competitive private school, St. B has the leverage to create and enforce rules governing parental involvement in the school community.

At the beginning of each school year, St. B Catholic School holds a mandatory parent meeting during which school rules and policies are reviewed. Failure to attend this meeting results in a \$25 fine charged to the student's tuition bill. Parents are also expected to sign an annual contract indicating that they agree to follow the school rules. These policies include a dress code and other rules that parents agree to enforce, and a parental agreement to supervise homework and sign their child's agenda book. Each family must also agree to contribute 25 hours of volunteer work. Parents can, however, choose not to volunteer, instead making an additional financial or in-kind contribution to the school.

This year St. B instituted a new policy designed to increase communication between parents and teachers. All parents of children in the first through third grades, without exception, are required to pick up their children in the classroom at the end of the school day. Parents are fined $\$ 1$ for every minute they are late.

It appeared that these expectations of parental involvement were closely aligned with the parents' understanding of their own responsibilities. For example, one parent mentioned that parent involvement in the school was one of the aspects she valued most about St. B. She explained: "There's more accountability here. You have to participate and what I like about this participation is that you get to know the other parents. Whereas in public schools it's more of a drop-off, baby-sit kind of deal." In reference to the 25 hours of mandatory volunteer work, she explained, "I like that because you're not taking things for granted ... Whichever way you can help you can put in those hours. You know they're there. That is your obligation." At least for this parent, there appeared to be an alignment between her own sense of responsibility and the expectations of the school.

At St. B, the edge that turns expectations into an internal accountability system is the fines imposed upon parents when they fail to meet expectations. The accountability system works most strongly here for parents, not teachers. Perhaps that is because the competition for admission to the school is greater than the competition for jobs at the school. Admission to St. B is extemely competi- 
tive, but the school administration has had difficulty recruiting qualified teachers.

\section{Pine Creek Elementary School}

Expectations that lead to an internal accountability system do not necessarily originate from administrators. At Pine Creek Elementary School, a strong set of expectations surround the subject of the students' capabilities and needs. These expectations function within the context of external policy, shaping personal responsibility and creating an internal accountability system.

Pine Creek Elementary School serves over 400 students from early childhood through grade five. Pine Creek is located in the city of Flagston, a suburb of a mid-sized eastern city. The school is located across the street from a large housing development where most of the students live. More than 75 percent of the students qualify for free or reduced price lunch.

In 1994 Pine Creek Elementary School was designated a Blue Ribbon School of Excellence by the United States Department of Education. The school was selected because it was one of four schools in the state with the largest relative gain in fourth grade reading scores. Not only did Pine Creek demonstrate significant growth, but the school scored significantly higher than other schools in its comparison school band.

Staff development at Pine Creek is designed to hold teachers accountable for meeting self-selected goals. Teachers meet in grade-level teams every Tuesday afternoon and work toward goals they have set as a team. At the end of the year, each team must present its progress to the principal who in turn reports to the main office. One teacher said she believed this system of staff development served to hold them accountable, "I think it's accountability. It's holding us as teachers accountable to the goals that we've set, and certainly often times it's harder to show what you've done if it's not something concrete, if there is not something written to hand to somebody."

Staff development team meetings are also used to discuss strategies for improving performance on standardized tests. Pine Creek has been designated as a Title I schoolwide project. The principal asserted that in order to maintain the additional level of funding associated with this designation, they must show 5 percent annual growth on the Stanford Achievement test.

Within the context of these expectations for student performance defined by the Title I law exists a set of collective expectations that relate to students' abilities. Unlike Turtle Haven, Pine Creek teachers define their work and expectations for students in relation to their understanding of the children's background. As one teacher explained, "Unfortunately, I've heard too many say around here that what we do here gets undone when they go home. The baggage that our kids carry with them when they come to school, sometimes it's unbelievable that they function as well as they do. So, a lot of them have a hard time, because there's nothing to look forward to after school gets out." Another teacher described the students' parents as follows: “They are one-parent families; they are all on welfare, they don't have any money for breakfast; they don't have any money for sub[sidized] lunch, and there is not very good parenting."

These perceptions of the students, parents, and community are often closely linked to teachers' academic expectations of students. Teachers explained that because of their backgrounds, students were not able to achieve as much academically as other students in Flagston. For example, one teacher explained that she was particularly proud of the progress the school has made in test scores because of the home environment of most students. 
How the teachers perceived their students and their backgrounds appeared to be the most influential factor in shaping teacher practice and attitudes. For example, the current principal has encouraged teachers to establish learning centers within classrooms. One teacher expressed frustration with this encouragement: "We found out that a lot of these types of children ... we've learned this through workshops and we've been told ... that this type of child that we have here needs more structure ... structure every inch of the way ... you know, less confusion and lots of structure that they thrive on."

Personal responsibility at Pine Creek is shaped by these expectations of students. Teachers perceived the children as extremely needy, both socially and academically. As a result, many teachers expressed a responsibility almost like the role of foster parent rather than the role of teacher. As one teacher said: "Kids today are coming in with a lot more issues, they are not being dealt with at home, and you need to deal with them. You wear many hats I think. That's your job-to do it, and it's your job to make sure you are doing it."

Teachers were involved in many activities with students outside of the regular school day. One teacher runs an extracurricular sports program, another volunteers as the unofficial school photographer. Another teacher mentioned that there were some things he does for which he does not believe he should be responsible. He referred to two crisis situations where he and the school got heavily involved in a student's home life. He explained, "Yeah, there's a lot of stuff we do here that we're not responsible for doing, but we do it just because we love the kids."

Some teachers, however, expressed frustration that the students' needs led the community to expect too much of teachers and the school. One teacher said: "I think we really need to gear more on the academic areas than on the other areas, whether it's the violence prevention or whatever areas are left to us, which is fine, but it's too bad because we have got enough to do with the academics. I mean it's expected that we provide breakfast, that we provide extra programs, we provide homework centers, and it's not so much well ... it's expected by some, appreciated by many."

Despite these frustrations, teachers continued to feel responsible for meeting the social and academic needs of their students. They perceive these needs to be the driving force behind most teachers' decisions. Many teachers expressed a conviction that in order to have success in their jobs, they had to assume responsibility for the many needs of their students. One teacher explained:
I think kids are coming in with so much extra baggage today, you can't get to the ABC's until you get past that point, and it would be ignorant of me to think that you could because you are not. If they don't come in ready to learn, you have to get them to that point; that's part of your job even if you have to spend all year on it.

Teachers' expectations of students also had a strong effect on the curriculum the teachers chose to introduce to students. Although there was a curriculum prescribed by the district, many teachers altered this curriculum based upon their perceptions of the children's needs and abilities. One teacher called Pine Creek a "home-based school" meaning:

We plan our curriculum for the kids down here based according to their needs because we know... what the type of the population there is down here. So we kind of gear the curriculum towards the needs of these kids because we know what the needs are and we know that sometimes the curriculum that is set for the entire city doesn't meet the needs of the kids. When they're saying that the kids should be reading such and such and we know these kids 
may come to us as non-readers... We do a lot of tutoring with the kids and we do a lot of changing the curriculum to meet their needs rather than to meet the needs of the city.

These expectations of students also appeared to shape the goals established by grade-level teams. For example, the third grade team chose to focus their efforts on teaching children to write in complete sentences. They felt that the activities provided for students were too complex and therefore chose to write their own set of questions to accompany the basal reader. One teacher explained that they "tried to write the questions from a literal standpoint because we found that the book was offering questions that were very evaluative and third graders could not do it. They were not developmentally ready to do that, but we found that they were ready to answer literal type questions in a complete sentence." In this instance, the collective expectations of students worked within an internal accountability system to lower expectations of student performance.

At Pine Creek the expectations formed among the teaching staff regarding students' needs are much stronger than any expectations from the district or principal. In the one area where the principal presented clear guidelines - staff development - these collective expectations shaped how the teachers met those guidelines. In this school, these collective expectations, closely aligned with the sense of personal responsibility to act as foster parents that most teachers feel, form the internal accountability system. As one teacher said, "You have to be willing to give extra time on Saturdays to come and watch them play basketball when they ask if you'll come to their game and you know nobody else will be there..."

The consequences at Pine Creek operate not so much on individual teachers, but for the entire school. The possible loss of Title I status, or loss of recognition and discretion, appeared to be a motivating factor behind much of the work of staff development teams. Teachers collaborated to create a plan that would help students achieve that minimum level of progress. Sometimes this included changing the curriculum, moving units out of the order they appear in the book, and strategically choosing which material to cover and which to skip. Pine Creek teachers and the principal felt pressure to achieve a five percent annual rise in test scores. This goal appeared to be consistent with the teachers' collective expectations of students, insofar as most teachers believed the children could improve and learn. However, if the school were expected to meet a criterion-based standard level, that might be less consistent with the school's established internal accountability systems.

\section{Summary}

The schools discussed in this section have managed to translate individual responsibility and collective expectations into some kind of internal accountability system. These internal accountability systems operate in the context of external policy, and sometimes the internal and external are mutually reinforcing. Such is the case when the external system, personal responsibility, and collective expectations are aligned within the school. At Turtle Haven, for example, the district's performance-based standards, although accompanied by little external accountability, appear closely aligned with the school's collective expectations. There is yet no defined mechanism to hold teachers accountable for the implementation of these standards, but this external policy has been incorporated into the internal accountability system.

In schools where the external policy is not aligned with the collective expectations, teachers tend to follow the internal accountability system. For example, at Pine Creek, teachers collectively decided that the district's curriculum was not appropriate for their students, still the school pays careful attention to the accountability system imposed by the federal Title I program. In effect, Pine Creek teachers wrote the district's curriculum based on their collective expecta- 
tions of students with lower abilities than those represented in the district's policy.

Internal accountability systems influence behavior because they reflect an alignment within the school of personal responsibility and collective expectations-regardless of the external policy. This alignment of expectations and responsibility is also accompanied by some sense that there will be consequences if expectations are not met. At Turtle Haven, teachers were aware that they could lose their jobs if they did not live up to the expectations set by the principal and reinforced by the school community. Parents at St. B's may feel some sense of responsibility to be involved in their children's education, but they know they will be fined if they do not follow the established guidelines.

It is the alignment between expectations and responsibility, connected to certain consequences, that shapes the internal accountability within these schools. All actors feel responsible for meeting expectations, and there are consequences for not meeting expectations. These expectations, however, are for the most part generated internally, or, if generated externally, are modified to match preexisting expectations within the school.

\section{Conclusion}

Our aim in this report has been to view the problem of accountability primarily from the perspective of schools, rather than from the perspective of external policies that purport to influence schools. In taking this perspective, we have aligned ourselves with those who ask what conditions within schools determine to whom, for what, and how they are accountable (Wagner 1989; Newmann, King, and Rigdon, 1997). In this sense, we have turned the traditional formulation of educational accountability, as a problem of public policy, inside out. Instead of asking how schools respond to policies designed to make them accountable to external authorities, we have asked how schools come to formulate their own conceptions of accountability and what role, if any, external policies play in these conceptions. Our working theory of accountability, and our research methods in this study, were predicated on the belief, or expectation, that external accountability systems operate on the margins of powerful factors inside the school, and that understanding these factors is a major precondition to understanding how and why schools respond the way they do to external pressures for accountability. In later phases of our research, in light of what we have learned from this study about how schools construct accountability, we will focus more explicitly on the design and implementation of external accountability systems.

The first and most important finding of this study is that our initial expectation about the power of school-level factors in shaping schools' conceptions of accountability was correct. All the schools in our study had distinctive solutions to the problem of to whom they were accountable for what. The relatively weak external accountability environment in which all of the schools operated offers some explanation for this lack of uniformity, but does not explain how or why schools arrive at the various configurations of accountability that we observed during our fieldwork. In most cases, solutions to the question of accountability were tacit, unarticulated, informal, and grew more from the individual beliefs and values of teachers and administrators as enacted in their daily practice, than from formal or explicit agreements.

The baseline, or default solution to accountability, that we observed at several schools was characterized by individual teacher responsibility, where personal discretion appeared to be dominant over organizational expectations or formalized accountability mechanisms. Phoenix Charter School typified this theme. The responsibilitydriven formulation of accountability evident in these schools was, in terms of our theoretical model, rather simplistic because it reflected little or no alignment with responsibility, expectations and accountability, and equally little coherence 
about teaching and learning. However, lack of complexity should not be mistaken for lack of influence on daily practice. Individual responsibility in these schools exerted a powerful influence over day-to-day operations, although the net result was a fragmented academic program.

Another group of schools, representing the midline of complexity in our sample, exhibited discernible effects of collective expectations within the school on individual teachers' conceptions of responsibility. St. Aloysius typified this formulation. In these schools where group expectations related to teaching and learning, the academic program was more coherent than in the first category of schools. Where expectations and individual responsibility were directed toward affective needs, coherence was again evident. These schools were distinguishable from our third category of schools in that alignment and coherence were the incidental result of the schools' expectations, but there was little structure or consequence associated with these expectations, and the object of these expectations-whether academic, affective, behavioral-was still largely discretionary.

The most complex formulation of accountability observed in our sample was represented by our third category of schools, led by Turtle Haven Pilot School. In these schools, collective expectations gelled into highly interactive, relatively coherent, informal and formal systems by which teachers and administrators held each other accountable for their actions vis a vis students. Teachers and administrators in this category of school were able to describe and interpret the formal external accountability systems in which their schools operated (such as testing systems, curriculum guidelines, charters, and the like), but in no case did these external systems seem to exercise the determining influence over their individual conceptions of responsibility, their collective expectations of each other or their students, or their internal accountability structures, where they existed.

Our findings did not accord with our initial expectations on one dimension. We expected that different types of schools would differ, if not systematically, at least roughly, in their solutions to the accountability problem. We deliberately designed the study to include parochial schools and charter schools, in addition to types of mainstream public schools in the belief that parochial schools and charter schools, as the empirical literature and claims of policymakers suggest, would present us with a stronger, clearer set of examples of internal accountability systems at work. For our sample, at least, this expectation proved not to be true. The development of a school's collective expectations and its internal accountability system in our sample seems to be more a function of particular school-level characteristics than it is a function of the type of school. We should not over-generalize this finding, but it is interesting that parochial schools and charters seemed to have the same problems as ordinary public schools in constructing a coherent conception of accountability.

This study confirms widely-prevalent views in sociological research that schools develop their own internal normative structures that are relatively immune to external influences, and that teaching is an essentially isolated occupation in which teachers are left largely to their own devices in deciding important issues of what and how to teach (Lortie 1975). But the framework and findings of this study advance this view in several respects. By distinguishing among individual conceptions of responsibility, collective expectations, and internal accountability structures, we have provided a finer-grained portrayal of the forces within schools that affect solutions to the accountability problem. The persistent isolation of teaching as an occupation, in our framework and findings, means that the school's conception of accountability collapses, by default, into individual teachers' conceptions of 
responsibility. Schools operating in this mode, such as Phoenix Charter, Gateway Elementary, and Hutchinson High, were typically characterized by an emphasis on order and control, possibly because this was the one collective expectation on which it is possible to reach agreement in an essentially isolated work environment. Perhaps because we conducted our fieldwork in relatively weak external accountability districts, we found that big questions about the collective purposes of the enterprise were often answered by the accretion of individual teachers' decisions, based on their views of their own and their students' capacities, rather than by collective deliberation or explicit management. The dominant pattern was not so much that schools developed their own strong internal normative structures that were in conflict with external influences, but rather that they failed to develop strong internal normative structures, and thereby defaulted to individual teachers on major issues of collective expectations and accountability. In such circumstances, a school's incidental solution to the accountability problem - to whom, for what, and how-became simply a collection of individual, often idiosyncratic, judgments by teachers, growing out of their backgrounds, capacities, and individual theories about what students can do or need.

In some cases, these judgments were powerfully influenced by teachers' preconceptions about their students' characteristics. Where teachers and administrators equated low socio-economic status with inevitably poor prospects for student learning, they frequently wrapped their low expectations in theories about the deprivation of students, their families, and their communities, uninformed by systematic knowledge of what students were capable of learning under different conditions of teaching. In other instances, teachers deliberately gave affective needs precedence over teaching and learning, but with the belief that physical, social and emotional deficits must be addressed before students could achieve at high levels. Hence, in several schools in our sample, teachers assigned the most powerful causality, in their own conceptions of responsibility, to factors over which they, as teachers, had little or no control, and assumed the least powerful causality to those over which they had the greatest control, the conditions of teaching and learning in the school.

The exceptions to the baseline, responsibilitydriven mode in our sample are instructive. They all challenge the isolation of teaching, often in halting and tentative ways, sometimes more aggressively and directly. And they do so usually by introducing the idea that collective expectations - among teachers, between teachers and students, between principals and teachers, and between families, communities, and schoolsshould influence individual teachers' conceptions of responsibility. Sometimes these collective expectations mirrored a culture of low expectations for students, but often they challenged these low expectations in important ways. At times collective expectations were therapeutic in nature-they cast the school in the role of substitute for deficient families and communities; sometimes they reflected the high academic expectations that school people attributed to families; and other times they explicitly aimed to correct low expectations of students in the community or the school. Usually, the development of more explicit collective expectations was associated with the presence of a principal whose model of leadership embodied an explicit attempt to overcome the isolation of teaching, by shaping the normative culture of the school through recruitment of teachers and through direct involvement in the instructional life of the school. And sometimes the development of a stronger set of collective expectations - through the active agency of a leader and the engagement of teachers-led to the creation of observable internal accountability structures, informal and formal, that carried real stakes and consequences for members of the organization. 
In our sample, the relationships between the external accountability structures within which schools operated and their internal solutions to the problems of responsibility, expectations, and accountability were slippery, subtle, and often downright contradictory. In the default mode, teachers and principals often dealt with the demands of formal external accountability structures (curriculum guidance, testing, and the like) either by incorporating them in superficial waysclaiming, for example, that they were consistent with existing practice when they clearly were not — or by rejecting them as unrealistic for the type of students they served. Without a way to address collective expectations within the school, external accountability measures can only work through individual teachers' conceptions of responsibility. Some teachers seemed quite adept at deflecting external accountability measures or unable to translate the accountability measures into daily practice. In instances where schools had developed some version of collective expectations, sometimes these expectations were aligned with external accountability systems, and sometimes they were not. In a few cases, we witnessed principals and teachers engaged in some sort of collective deliberation about how to incorporate external accountability requirements into their internal conceptions of responsibility, expectations, and accountability. But, in most cases, teachers and principals viewed external accountability systems like the weather-something that might affect their daily lives in some way, something they could protect themselves against, but not something they could or should do much about. In a few cases, the responses of teachers and principals to external accountability systems seemed to contradict in some fundamental way the theory behind the external systems, such as the charter schools in our study that seemed to experience no special demands or requirements stemming from the need for their charters to be renewed.

This finding about the slippery, subtle, and contradictory relationship between internal and external accountability may simply be an artifact of the design of our study. We deliberately did not, at this stage, seek schools that were operating in strong and obtrusive external accountability systems. Some schools in our sample were located in cities that are in the early stages of developing stronger external accountability systems. Some cities are located in states that are in the early stages of implementing a new accountability system. The charter laws operating in the states where we conducted our study were in the early stages of implementation and these states had not yet directly confronted the issue of charter renewal. The weakness of the effects of external accountability systems may simply be attributable to the state of policy. We will confront this issue more explicitly in later stages of the study, when we will observe schools in more visible and powerful external accountability environments.

Taking the limitations of our design and sample into account, there are still important things to be learned from this initial study about the relationship between internal and external accountability systems. It seems highly unlikely to us that schools operating in the default mode-where all questions of accountability related to student learning are essentially questions of individual teacher responsibility, will be capable of responding to strong, obtrusive external accountability systems in ways that lead to systematic, deliberate improvement of instruction and student learning. The idea that a school will improve its instructional practice and, therefore, the overall performance of its students implies a capacity for collective deliberation and action that schools in our sample did not exhibit. Where virtually all decisions about accountability are decisions made by individual teachers, based on their individual conceptions of what they and their students can do, it seems unlikely that these decisions will somehow aggregate into overall improvement for the school. For schools operating in the default mode, the question for future research on the effect of external accountability systems is whether these schools can, or will, respond by developing congruent internal expectations and accountability systems. Perhaps more importantly, a 
related question is how these schools will get the capacity to develop these new internal norms and processes.

Schools that are not in the default mode-schools that have developed internal expectations, internal accountability systems, or both-raise a different set of issues about the relationship between internal and external accountability. Our study suggests that these schools answer the for-whatthey-are-accountable question in very different ways-some schools focus on students' affective needs, others on high aspirations for students' academic performance. For these schools, the issues are: the degree of alignment between their internal expectations and accountability systems and the demands of external systems; and the level of conflict and accommodation that arises from the confrontation between internal and external accountability. Are schools that manifest some capacity to deal collectively with the accountability problem internally more likely to adapt and align their internal norms and systems to the requirements of external systems, or are they likely to be more resistant to changing their internal norms and systems? Do these schools have the capacities necessary to do the work of accommodating and adapting new external requirements? The existence of internal expectations and accountability structures, in other words, does not necessarily predict how a school will respond to new external requirements regarding teaching and learning. We will pursue these questions in the next phase of our research.

In this report, we have tried to array schools in a three-fold typology showing the range of accountability formulations that we observed in our fieldwork: schools in the default mode where all questions of accountability for student learning collapse into questions of individual teacher responsibility; schools that exhibit common expectations that influence and are influenced by individual conceptions of responsibility; and schools where expectations and individual respon- sibility are aligned to such an extent that this combination effectively functions as an internal accountability systems with stakes and consequences for members of the organization. The edges of these three types of schools are blurry in interesting and informative ways, suggesting both the possible limits of our working theory and the diversity of ways that schools have of coping with the accountability problem.

One thing, however, seems quite clear from our study to date. Conditions within schools are logically and empirically prior to conditions outside schools when constructing a working theory of educational accountability. That is, we cannot know how an accountability system will work, nor can we know how to design such a system, unless we know how schools differ in the way they construct responsibility, expectations, and internal accountability. This finding is fundamental to the study of educational accountability in all its forms. Schools will vary in their response to external accountability systems depending on the level and type of solutions they have in place to the problems of responsibility, expectations, and internal accountability. Studies of accountability and attempts to design new accountability systems will succeed to the degree that they consider the sources of variability and explain their impact on the way schools respond to external demands. Accountability systems are often constructed by policymakers and administrators out of normative theories of how schools ought to act, uncorrupted by understandings of why they act the way they do. Our study suggests that such systems should take their initial point of departure not from normative theories about how schools ought to act, but from a finer-grained understanding of why they act the way they do.

Our research also suggests that the attitudes, values, and beliefs of individual teachers and administrators - about what students can do, about what they can expect of each other, and about the relative influence of student, family, community, and school on student learning — are key 
factors in determining the solutions that schools construct to the accountability problem. Put bluntly, many educators simply do not believe that they have the capacity to influence student learning in the ways that external accountability systems suggest they should. Hence, external accountability systems will be relatively powerless in the absence of changed conceptions of individual responsibility and collective expectations within schools. In our study, we have come to call this problem: "when accountability knocks, is anyone home?" A strong normative environment inside the school, based on a belief in the capacity and efficacy of teachers and principals to influence student learning, coupled with the knowledge and skill necessary to act on those beliefs are prior conditions necessary to the success of strong external accountability systems. 


\section{References}

Elmore, Richard F. (1997). The politics of education reform. Issues in Science and Technology, XIV(1).

Ladd, Helen. (1996). Holding schools accountable: Performance based reform in education. Washington, DC: Brookings Institute.

Lortie, Daniel C. (1975). Schoolteacher: A Sociological Study. Chicago, IL: University of Chicago Press.

Metz, Mary Haywood. (1990). How social class differences shape teachers' work. In M. W. McLaughlin, J. E. Talbert, \& N. Bascia (Eds.), The contexts of teaching in secondary schools: Teachers' realities (pp. 40-107). New York, NY: Teachers College Press.

Metz, Mary Haywood. (1990). Real school: A universal drama amid disparate experience. In D. E. Mitchell \& M. E. Goertz (Eds.), Education politics for the new century. New York, NY: Falmer Press.

Newmann, Fred, King, Bruce, \& Rigdon, Mark. (1997). Accountability and school performance: Implications from restructuring schools. Harvard Educational Review, 67(1) 41-74.

Schein, Edgar H. (1992). Organizational culture and leadership. San Francisco, CA: Jossey Bass.

Wagner, Robert B. (1989). Accountability in education: A philosophical inquiry. New York, NY: Routledge. 


\begin{tabular}{|c|c|c|}
\hline \multicolumn{3}{|c|}{$\begin{array}{c}\text { Appendix 1 } \\
\text { Interview Protocol } \\
\text { Interview Questions for Teachers }\end{array}$} \\
\hline Direct & Indirect & Hybrid \\
\hline $\begin{array}{l}\text { 1. As a teacher, what are you held } \\
\text { accountable for? }\end{array}$ & 1. As a teacher, what is your job? & $\begin{array}{l}\text { 1. As a teacher, what are you } \\
\text { expected to do? }\end{array}$ \\
\hline $\begin{array}{l}\text { 2. How do you know when you're in } \\
\text { compliance? }\end{array}$ & $\begin{array}{l}\text { 2. How do you know when you're doing } \\
\text { your job well? }\end{array}$ & $\begin{array}{l}\text { 2. To whom do you feel the } \\
\text { greatest sense of responsibility? }\end{array}$ \\
\hline $\begin{array}{l}\text { 3. Do you think there's a common } \\
\text { perception in your school regarding } \\
\text { what you're all accountable for? }\end{array}$ & $\begin{array}{l}\text { 3. Do you think most teachers in your } \\
\text { school would answer the same way, or } \\
\text { differently? }\end{array}$ & $\begin{array}{l}\text { 3. Do you think most of the } \\
\text { teachers in your school have the } \\
\text { same point of view regarding } \\
\text { their responsibilities? }\end{array}$ \\
\hline 4. To whom are you accountable? & $\begin{array}{l}\text { 4. Who determines whether you're doing } \\
\text { your job well, and how is that } \\
\text { determined? }\end{array}$ & $\begin{array}{l}\text { 4. What makes a school year } \\
\text { "good" or "bad" for you? }\end{array}$ \\
\hline $\begin{array}{l}\text { 5. What formal accountability measures } \\
\text { are in place at your school? }\end{array}$ & $\begin{array}{l}\text { 5. Are the formal assessments of } \\
\text { students used in your school an accurate } \\
\text { measure of achievement and of your } \\
\text { teaching? }\end{array}$ & $\begin{array}{l}\text { 5. What does your school } \\
\text { principal expect of you and does } \\
\text { he/she expect the same of } \\
\text { everyone? }\end{array}$ \\
\hline $\begin{array}{l}\text { 6. Are those formal accountability } \\
\text { mechanisms an accurate measure of } \\
\text { your teaching and student } \\
\text { achievement? }\end{array}$ & $\begin{array}{l}\text { 6. How well does the content of those } \\
\text { measures map the content of what you } \\
\text { do in the classroom? }\end{array}$ & $\begin{array}{l}\text { 6. How would you alter the } \\
\text { assessments your school } \\
\text { currently uses to make them } \\
\text { more useful and/or informative? }\end{array}$ \\
\hline $\begin{array}{l}\text { 7. How are the measures used? (i.e., } \\
\text { who sees the results, what happens } \\
\text { when students/teachers do well/poorly } \\
\text { on these measures)? }\end{array}$ & $\begin{array}{l}\text { 7. Who or what has an influence (or the } \\
\text { greatest influence) over what you do in } \\
\text { the classroom? }\end{array}$ & $\begin{array}{l}\text { 7. How do you think the external } \\
\text { community perceives your } \\
\text { school? }\end{array}$ \\
\hline $\begin{array}{l}\text { 8. What role do parents, and the larger } \\
\text { community play in your school, and how } \\
\text { does that compare to what you think } \\
\text { their role should be? }\end{array}$ & $\begin{array}{l}\text { 8. What role do parents, and the larger } \\
\text { community play in your school, and how } \\
\text { does that compare to what you think their } \\
\text { role should be? }\end{array}$ & $\begin{array}{l}\text { 8. What role do parents, and the } \\
\text { larger community play in your } \\
\text { school, and how does that } \\
\text { compare with what you think their } \\
\text { role should be? }\end{array}$ \\
\hline 9. Who is accountable to you? & $\begin{array}{l}\text { 9. Are other teachers or your principal } \\
\text { answerable to you for anything? } \\
\text { (Students?) }\end{array}$ & $\begin{array}{l}\text { 9. What do you expect of other } \\
\text { teachers? Of your principal? Are } \\
\text { they formally responsible to you } \\
\text { in any way? (Students?) }\end{array}$ \\
\hline $\begin{array}{l}\text { 10. Are there any conditions under } \\
\text { which you believe you should not be } \\
\text { held accountable, or should be less } \\
\text { accountable, for your student's } \\
\text { learning? }\end{array}$ & $\begin{array}{l}\text { 10. What level of schooling do you think } \\
\text { most of your students will achieve? }\end{array}$ & $\begin{array}{l}\text { 10. What factors do you believe } \\
\text { influence students' achievement, } \\
\text { and which of those are you in a } \\
\text { position to affect? }\end{array}$ \\
\hline $\begin{array}{l}\text { 11. If you were hiring a teacher for your } \\
\text { position, what characteristics would you } \\
\text { look for? }\end{array}$ & $\begin{array}{l}\text { 11. If you were hiring a teacher for your } \\
\text { position, what characteristics would you } \\
\text { look for? }\end{array}$ & $\begin{array}{l}\text { 11. If you were hiring a teacher } \\
\text { for your position, what } \\
\text { characteristics would you look } \\
\text { for? }\end{array}$ \\
\hline
\end{tabular}




\begin{tabular}{|c|c|c|}
\hline \multicolumn{3}{|c|}{ Interview Questions for Parents } \\
\hline Direct & Indirect & Hybrid \\
\hline $\begin{array}{l}\text { 1. Who is accountable for your child's } \\
\text { learning? }\end{array}$ & $\begin{array}{l}\text { 1. Whose job is it to ensure that your } \\
\text { children are learning? }\end{array}$ & $\begin{array}{l}\text { 1. Who is responsible for your } \\
\text { child's learning? }\end{array}$ \\
\hline $\begin{array}{l}\text { 2. How do you know whether your child } \\
\text { is learning? }\end{array}$ & $\begin{array}{l}\text { 2. How do you know whether your child is } \\
\text { learning? }\end{array}$ & $\begin{array}{l}\text { 2. How do you know whether } \\
\text { your child is learning? }\end{array}$ \\
\hline $\begin{array}{l}\text { 3. For what information, and by what } \\
\text { means, is your child's school required to } \\
\text { give an account of student learning and } \\
\text { school standing? }\end{array}$ & $\begin{array}{l}\text { 3. What information regarding your child's } \\
\text { progress, and the school's scores, is the } \\
\text { school required to share with you, and } \\
\text { how is that info conveyed? (meetings, } \\
\text { report cards, media, etc.) }\end{array}$ & $\begin{array}{l}\text { 3. What information regarding } \\
\text { your child's learning, and the } \\
\text { school's standing do you expect } \\
\text { the school to provide? How do } \\
\text { you expect that information to be } \\
\text { conveyed? }\end{array}$ \\
\hline $\begin{array}{l}\text { 4. If your child were having difficulty with } \\
\text { his/her work, who is accountable to } \\
\text { address that problem? }\end{array}$ & $\begin{array}{l}\text { 4. If your child were having difficulty with } \\
\text { his/her work, what would you do, or } \\
\text { advise your child to do? }\end{array}$ & $\begin{array}{l}\text { 4. If your child were having } \\
\text { difficulty with his/her work, who } \\
\text { would you expect to address that } \\
\text { problem, and what would you } \\
\text { expect to happen in addressing } \\
\text { it? }\end{array}$ \\
\hline $\begin{array}{l}\text { 5. What do you feel accountable for in } \\
\text { regard to your child's learning? }\end{array}$ & $\begin{array}{l}\text { 5. What is your role in your child's } \\
\text { learning? }\end{array}$ & $\begin{array}{l}\text { 5. What do you feel responsible } \\
\text { for in regard to your child's } \\
\text { learning? }\end{array}$ \\
\hline $\begin{array}{l}\text { 6. What do you think your child's } \\
\text { teacher holds you accountable for, and } \\
\text { why do you think that? }\end{array}$ & $\begin{array}{l}\text { 6. What do you think your child's teacher } \\
\text { and principal believe your role is? }\end{array}$ & $\begin{array}{l}\text { 6. What do your child's teacher } \\
\text { and principal expect of you in } \\
\text { regard to your child's education? }\end{array}$ \\
\hline $\begin{array}{l}\text { 7. Who is accountable for discipline in } \\
\text { your child's classroom and the school } \\
\text { as a whole? }\end{array}$ & $\begin{array}{l}\text { 7. Whose job is it to maintain discipline } \\
\text { in your child's school? }\end{array}$ & $\begin{array}{l}\text { 7. Who is responsible for } \\
\text { maintaining discipline in the } \\
\text { school? }\end{array}$ \\
\hline $\begin{array}{l}\text { 8. What type/degree of school-site } \\
\text { involvement should parents be } \\
\text { accountable for? }\end{array}$ & $\begin{array}{l}\text { 8. What type/degree of school-site } \\
\text { involvement is appropriate for parents? }\end{array}$ & $\begin{array}{l}\text { 8. What type/degree of school- } \\
\text { site involvement should parents } \\
\text { be responsible for? }\end{array}$ \\
\hline $\begin{array}{l}\text { 9. How does this compare with yours } \\
\text { and other parents' involvement? }\end{array}$ & $\begin{array}{l}\text { 9. How does this compare with yours and } \\
\text { other parents' involvement? }\end{array}$ & $\begin{array}{l}\text { 9. How does this compare with } \\
\text { your and other parents' } \\
\text { involvement? }\end{array}$ \\
\hline $\begin{array}{l}\text { 10. If you had (have) the option to send } \\
\text { your child elsewhere, would you? Why? }\end{array}$ & $\begin{array}{l}\text { 10. If you had (have) the option to send } \\
\text { your child elsewhere, would you? Why? }\end{array}$ & $\begin{array}{l}\text { 10. If you had (have) the option } \\
\text { to send your child elsewhere, } \\
\text { would you? Why? }\end{array}$ \\
\hline $\begin{array}{l}\text { 11. What do you expect students to } \\
\text { know upon entering your class? } \\
\text { Leaving? }\end{array}$ & $\begin{array}{l}\text { 11. What do you expect students to } \\
\text { know upon entering your class? } \\
\text { Leaving? }\end{array}$ & $\begin{array}{l}\text { 11. What do you expect students } \\
\text { to know upon entering your } \\
\text { class? Leaving? }\end{array}$ \\
\hline
\end{tabular}




\begin{tabular}{|c|c|c|}
\hline \multicolumn{3}{|c|}{ Interview Questions for Principals/Administrators } \\
\hline Direct & Indirect & Hybrid \\
\hline 1. What are you accountable for? & $\begin{array}{l}\text { 1. As a principal/administrator, what's } \\
\text { your job? }\end{array}$ & $\begin{array}{l}\text { 1. As principal/administrator, } \\
\text { what are you responsible for? }\end{array}$ \\
\hline 2. To whom are you accountable? & $\begin{array}{l}\text { 2. Who determines whether you're doing } \\
\text { your job well, and how is that } \\
\text { determined? }\end{array}$ & $\begin{array}{l}\text { 2. Who determines whether } \\
\text { you're fulfilling your responsibility } \\
\text { and meeting expectations? }\end{array}$ \\
\hline $\begin{array}{l}\text { 3. What do you hold teachers } \\
\text { accountable for? }\end{array}$ & $\begin{array}{l}\text { 3. What is the job of teachers in your } \\
\text { school? }\end{array}$ & $\begin{array}{l}\text { 3. What do you expect teacher's } \\
\text { to be responsible for in your } \\
\text { school? }\end{array}$ \\
\hline $\begin{array}{l}\text { 4. By what means, formal and informal, } \\
\text { is that accountability enforced? }\end{array}$ & $\begin{array}{l}\text { 4. How do you know whether they're } \\
\text { doing their jobs well, and is there a } \\
\text { common understanding/procedure for } \\
\text { what happens if they don't? }\end{array}$ & $\begin{array}{l}\text { 4. How do you know whether } \\
\text { they're doing their jobs well, and } \\
\text { what is the expectation about } \\
\text { what happens if they don't? } \\
\text { (Yours and theirs?) }\end{array}$ \\
\hline $\begin{array}{l}\text { 5. Do you believe teachers in your } \\
\text { school have a clear sense of what } \\
\text { they're held accountable for? }\end{array}$ & $\begin{array}{l}\text { 5. Do you believe teachers have a clear } \\
\text { sense of what their job is? Why or why } \\
\text { not? }\end{array}$ & $\begin{array}{l}\text { 5. Do teachers know what's } \\
\text { expected of them, and how do } \\
\text { they know? }\end{array}$ \\
\hline $\begin{array}{l}\text { 6. How well do the formal assessments } \\
\text { used at your school reflect student } \\
\text { achievement and teaching? }\end{array}$ & $\begin{array}{l}\text { 6. What happens if a teacher is not } \\
\text { doing his/her job? }\end{array}$ & $\begin{array}{l}\text { 6. What happens if teachers are } \\
\text { not doing what's expected of } \\
\text { them? }\end{array}$ \\
\hline $\begin{array}{l}\text { 7. How are results of assessments } \\
\text { used in your school? (Who sees them } \\
\text { or how well do they reflect what they're } \\
\text { doing in the classroom?) }\end{array}$ & $\begin{array}{l}\text { 7. How well do the formal assessments } \\
\text { used at your school reflect your, and } \\
\text { teachers' efforts at improving student } \\
\text { achievement and teaching? }\end{array}$ & $\begin{array}{l}\text { 7. How well do formal } \\
\text { assessments used at your school } \\
\text { reflect your expectations, and } \\
\text { those of teachers, for student } \\
\text { achievement and teaching } \\
\text { effectiveness? }\end{array}$ \\
\hline $\begin{array}{l}\text { 8. What characteristics do you look for } \\
\text { when hiring a new teacher? }\end{array}$ & $\begin{array}{l}\text { 8. What characteristics do you look for } \\
\text { when hiring a new teacher? }\end{array}$ & $\begin{array}{l}\text { 8. What characteristics do you } \\
\text { look for when hiring a new } \\
\text { teacher? }\end{array}$ \\
\hline $\begin{array}{l}\text { 9. Since the beginning of this year, what } \\
\text { has been your most challenging internal } \\
\text { issue? }\end{array}$ & $\begin{array}{l}\text { 9. Since the beginning of this year, what } \\
\text { has been your most challenging internal } \\
\text { issue? }\end{array}$ & $\begin{array}{l}\text { 9. Since the beginning of this } \\
\text { year, what has been your most } \\
\text { challenging internal issue? }\end{array}$ \\
\hline $\begin{array}{l}\text { 10. Since the beginning of the year, } \\
\text { what was the most challenging } \\
\text { externally-generated issue? }\end{array}$ & $\begin{array}{l}\text { 10. Since the beginning of the year, what } \\
\text { was the most challenging externally- } \\
\text { generated issue? }\end{array}$ & $\begin{array}{l}\text { 10. Since the beginning of the } \\
\text { year, what was the most } \\
\text { challenging externally-generated } \\
\text { issue? }\end{array}$ \\
\hline $\begin{array}{l}\text { 11. Upon leaving your school, what } \\
\text { should students know (and be able to } \\
\text { do)? }\end{array}$ & $\begin{array}{l}\text { 11. Upon leaving your school, what } \\
\text { should students know (and be able to } \\
\text { do)? }\end{array}$ & $\begin{array}{l}\text { 11. Upon leaving your school, } \\
\text { what should students know (and } \\
\text { be able to do)? }\end{array}$ \\
\hline
\end{tabular}




\begin{tabular}{|c|c|c|}
\hline \multicolumn{3}{|c|}{ Interview Questions for Students } \\
\hline Direct & Indirect & Hybrid \\
\hline $\begin{array}{l}\text { 1. As a student, what are you } \\
\text { accountable for? }\end{array}$ & 1. What is your "job" as a student? & $\begin{array}{l}\text { 1. As a student, what are you } \\
\text { expected to do? }\end{array}$ \\
\hline $\begin{array}{l}\text { 2. To whom are you accountable? } \\
\text { How? }\end{array}$ & $\begin{array}{l}\text { 2. Who holds you responsible for doing } \\
\text { your "job" as a student? How? }\end{array}$ & $\begin{array}{l}\text { 2. Who holds you responsible for } \\
\text { fulfilling those expectations? } \\
\text { How? }\end{array}$ \\
\hline $\begin{array}{l}\text { 3. How do you know when you're doing } \\
\text { well in school? (How do you know when } \\
\text { you've learned a subject or lesson?) }\end{array}$ & $\begin{array}{l}\text { 3. How do you know when you're doing } \\
\text { well in school? (How do you know when } \\
\text { you've learned a subject or lesson?) }\end{array}$ & $\begin{array}{l}\text { 3. How do you know when you're } \\
\text { doing well in school? (How do } \\
\text { you know when you've learned a } \\
\text { subject or lesson?) }\end{array}$ \\
\hline $\begin{array}{l}\text { 4. How is your school achievement } \\
\text { measured? }\end{array}$ & $\begin{array}{l}\text { 4. How is your school achievement } \\
\text { measured? }\end{array}$ & $\begin{array}{l}\text { 4. How is your school } \\
\text { achievement measured? }\end{array}$ \\
\hline $\begin{array}{l}\text { 5. Who is accountable for your } \\
\text { learning? }\end{array}$ & $\begin{array}{l}\text { 5. Who's job is it to make sure you } \\
\text { learn? }\end{array}$ & $\begin{array}{l}\text { 5. Who is responsible for your } \\
\text { learning? }\end{array}$ \\
\hline $\begin{array}{l}\text { 6. As a student, is anyone accountable } \\
\text { to you? }\end{array}$ & $\begin{array}{l}\text { 6. Is anyone in your school (adults or } \\
\text { other students) answerable to you as a } \\
\text { student? }\end{array}$ & $\begin{array}{l}\text { 6. What do you expect of others, } \\
\text { adults and students, in your } \\
\text { school? }\end{array}$ \\
\hline $\begin{array}{l}\text { 7. What makes a teacher a good } \\
\text { teacher? }\end{array}$ & $\begin{array}{l}\text { 7. What makes a teacher a good } \\
\text { teacher? }\end{array}$ & $\begin{array}{l}\text { 7. What makes a teacher a good } \\
\text { teacher? }\end{array}$ \\
\hline $\begin{array}{l}\text { 8. What makes a school a good } \\
\text { school? }\end{array}$ & 8. What makes a school a good school? & $\begin{array}{l}\text { 8. What makes a school a good } \\
\text { school? }\end{array}$ \\
\hline $\begin{array}{l}\text { 9. How would you describe a good } \\
\text { school year? (Or week?) }\end{array}$ & $\begin{array}{l}\text { 9. How would you describe a good } \\
\text { school year? (Or week?) }\end{array}$ & $\begin{array}{l}\text { 9. How would you describe a } \\
\text { good school year? (Or week?) }\end{array}$ \\
\hline $\begin{array}{l}\text { 10. What are you expected to know, be } \\
\text { able to do when you finish }(x) \text { grade? }\end{array}$ & $\begin{array}{l}\text { 10. What are you expected to know, be } \\
\text { able to do when you finish }(x) \text { grade? }\end{array}$ & $\begin{array}{l}\text { 10. What are you expected to } \\
\text { know, be able to do when you } \\
\text { finish }(x) \text { grade? }\end{array}$ \\
\hline $\begin{array}{l}\text { 11. What do you think you'll be doing } 5- \\
10 \text { years from now? }\end{array}$ & $\begin{array}{l}\text { 11. What do you think you'll be doing } 5 \text { - } \\
10 \text { years from now? }\end{array}$ & $\begin{array}{l}\text { 11. What do you think you'll be } \\
\text { doing } 5-10 \text { years from now? }\end{array}$ \\
\hline
\end{tabular}




\section{End Notes}

${ }^{1}$ Newmann, et al 1997 identify a "complete school accountability system" as including: (1) Information about the organization's performance (e.g., test scores); (2) Standards for judging the quality or degree of success of organizational performance (e.g., a mean achievement score higher than other schools with comparable demographic characteristics); (3) Significant consequences to the organization (i.e., rewards and sanctions such as bonuses to teachers in the school) for its success or failure in meeting specified standards; and (4) An agent or constituency that receives information on organizational performance, judges the extent to which standards have been met, and distributes rewards and sanctions (e.g., the state department of instruction).

${ }^{2}$ See Elmore, Education Policy and Practice in the Aftermath of TIMSS, 1997.

${ }^{3}$ The research reported in this paper was part of the CPRE research project, “Accountability for Results, Capacity for Reform,” jointly undertaken by Stanford and Harvard Universities.

${ }^{4}$ Our working theory is informed by Robert Wagner's conception of accountability and responsibility, as described in Accountability in Education, 1989.

5 See Newmann, et al. 1997

6 See Metz, in Mitchell and Goertz, eds., 1990 for more on "Real Schools," and standard constructions of schooling.

7 In some cases, the categorization of schools is a better fit than in others. Full case studies of each school are available upon request by contacting CPRE-Harvard. 